\title{
Offer Price Information and the Exercise of Market Power: The Effect of the Publication of the Historical Trading Report on Competition in the Alberta Electricity Market
}

\author{
Derek E. H. Olmstead, ${ }^{a}$ Matthew J. Ayres, ${ }^{b}$ and Peter B. R. Lomas ${ }^{c}$
}

\begin{abstract}
This paper considers the effect of the publication of offer price information on unilateral market power in Alberta's electricity market. This market is an hourly auction characterized by repeated interaction among a small number of producers, common knowledge of costs and production capabilities, and price inelastic demand.

For the period July 13, 2000 to May 18, 2017, offer prices for each hour were published by the market operator, the Alberta Electric System Operator (AESO), in the Historical Trading Report (HTR) after the end of the hour. Using counterfactual analysis from 2010 to 2015 (52,584 hours), the paper finds that the effect of offer price changes after the HTR publication was to raise the average hourly price for electricity in Alberta by $\$ 2.48 / \mathrm{MWh}$ or about $4.2 \%$, which raised the cost of electricity for Alberta consumers during the six-year period by approximately $\$ 1.14$ billion.

Based on an earlier version of this paper, the AESO was instructed by Alberta's utilities regulator to cease publication of the HTR.
\end{abstract}

Keywords: Electricity, Market power, Information, Auction design, Antitrust

https://doi.org/10.5547/01956574.41.SI1.dolm

\section{INTRODUCTION}

Alberta's electricity market is organized as an auction in which producers compete to meet consumers' demand for electricity in each delivery hour. These auctions are conducted by the province's independent system operator, the Alberta Electric System Operator (AESO). During the period from July 13, 2000 to May 18, 2017, the AESO published the Historical Trading Report (HTR) that, about 5 to 10 minutes after the end of each delivery hour, made public the prices and quantities of each offer to supply energy in the delivery hour just ended.

Information about current or recent producer offer strategies is not commonly available in other liberalised electricity markets. As such, the experience of Alberta in releasing this information may serve as an indicator as to whether other markets should adopt this disclosure or remain cautious about the release of such information.

a Corresponding author. Administrator, Alberta Market Surveillance Administrator; Adjunct Research Professor, Department of Economics, Carleton University; and Adjunct Assistant Professor, Department of Economics, University of Calgary. Email: derek.olmstead@ucalgary.ca and derek.olmstead@carleton.ca.

b Chief Economist, Alberta Market Surveillance Administrator and Executive Fellow, School of Public Policy and Adjunct Assistant Professor, Department of Economics, University of Calgary. Email: matt.ayres@ucalgary.ca.

c Senior Manager, Financial Analysis, Ofgem. Email: peter.lomas@ofgem.gov.uk. 
Theoretical predictions about the effect of information publication in the context of non-cooperative competition are not definitive: information may enhance the competitiveness of the market and result in lower market prices, it may diminish the competitiveness of the market and result in higher market prices, or it may have no effect on prices. As such, how the publication of information affects competition and market outcomes is context-dependent. The purpose of this paper is to report an empirical assessment of the publication of very recent offer prices through the HTR on outcomes in the Alberta electricity market and to draw insights into how information affects market outcomes in electricity markets more generally.

For each delivery hour, all generators are required to make initial offers, which are comprised of prices and quantities, for their generation capacity by noon on the day before delivery. These offers may be restated up to two hours before the beginning of the delivery hour. This paper uses a confidential database of all initial offers and restatements (changes to offers that have already been made) made by generators in Alberta during the period 2010 to 2015, a total of 52,584 hours. The methodology is to take observed market prices and compare them to those that would have resulted if restatements that resulted in changed offer prices following the publication of the final HTR did not occur. It is then calculated whether, on average, market prices are higher than those that would have resulted if the restatements did not occur. If so, then there is evidence that the information contained in the HTR facilitates learning that allows for the increased exercise of unilateral market power.

While the analysis indicates that there are hours in which the publication of the HTR contributed to both higher and lower market prices, the analysis finds that offer restatements that occur after the publication of the final HTR raised the hourly Alberta electricity price by an average of $\$ 2.48 / \mathrm{MWh}$, about $4.2 \%$, over the 6-year period from 2010 to 2015 . This raised the aggregate value of electricity consumption in Alberta during the six-year period by approximately $\$ 1.14$ billion.

It was on the basis of an earlier version of these findings that the Alberta Utilities Commission, Alberta's public utilities and electricity market regulator, at the request of the Market Surveillance Administrator, Alberta's electricity market monitor, ordered the AESO to cease publication of the HTR, which it did on May 18, 2017.

The paper is structured as follows. Section 2 provides a background description of Alberta's electricity market, during the period 2010 to 2015, and the role of the HTR. Section 3 discusses analytical frameworks for considering the effect of information on competition and reviews existing analyses of the HTR. Section 4 details the creation of the database of confidential offers used in this paper and the rationale for the selection of the study period. Section 5 describes an empirical strategy to construct counterfactual market prices that reflect the effect of the publication of the HTR. Section 6 provides results and discussion of this empirical strategy, including a detailed discussion of offer behaviour in the Alberta electricity market in a specific hour. Section 7 reports an econometric assessment of the impact of the publication of the HTR. Section 8 concludes.

\section{THE ALBERTA ELECTRICITY MARKET AND THE HISTORICAL TRADING REPORT}

\subsection{Supply and demand in the Alberta power pool}

The wholesale electricity market in Alberta is structured as a gross power pool. A gross power pool is a market in which any firm that wishes to produce and sell electricity is required to do so through a central, jurisdiction-wide auction and bilateral physical transactions between producers and consumers located at different locations are not allowed. Forward financial bilateral and 
exchange trading does occur. The power pool is operated by the AESO as a sequence of distinct auctions for the delivery of electric energy in a single delivery hour.

Producers may offer their energy at any price between $\$ 0 / \mathrm{MWh}$ and $\$ 999.99 / \mathrm{MWh}$. For each delivery hour, producers must submit initial offers to the AESO before noon on the day before the delivery hour (and may do so up to seven days in advance). Producer offers for each generating asset consist of up to seven offer blocks with each block defined by a unique offer price and an associated offer quantity called a price-quantity pair (PQ pair). The sum of offer block quantities made for each generating asset in each delivery hour must exactly equal the maximum capability of the generating asset, which is a technical parameter that is registered with the AESO and does not vary on an hour-to-hour basis. ${ }^{1}$

In addition to the submission of offer blocks, each generating asset must declare a single value for its available capability in each delivery hour. This is a technical parameter that represents the generating asset's expected ability to physically produce electric energy in the delivery hour. It must be less than or equal to the generating asset's maximum capability and greater than or equal to zero. If a generating asset's available capability is less than its maximum capability, the reason(s) for this physical condition must be provided to the AESO. Common reasons include an outage for planned maintenance or a derating due to warm weather that reduces the ability of the generating asset to cool itself thereby limiting its ability to produce output. Importantly, it is not acceptable to declare an available capability less than maximum capability for purely economic reasons; this restriction constitutes a so-called must-offer rule.

As indicated in Table 1 the five largest firms in the market controlled between 65 and $70 \%$ of generation capacity over the years 2010 to 2015 (as discussed further below, this is the study period of the analysis reported in this paper). As indicated in Table 2, the fraction of total electricity production by generation technology was relatively stable across the years in the study period, though there was a slight downward trend of production from coal-fired generators that was offset by increased production from natural gas-fired generators and wind-powered generators. For a more thorough discussion of features of the Alberta wholesale electricity market, see Olmstead and Ayres (2014).

Table 1: Share of generation capacity controlled by major market participants

\begin{tabular}{|c|c|c|c|c|c|c|}
\hline Firm & 2010 & 2011 & 2012 & 2013 & 2014 & 2015 \\
\hline ATCO & $11.1 \%$ & $10.6 \%$ & $10.3 \%$ & $9.8 \%$ & $11.8 \%$ & $10.5 \%$ \\
\hline Capital Power & $9.3 \%$ & $10.6 \%$ & $10.5 \%$ & $10.4 \%$ & $10.3 \%$ & $10.9 \%$ \\
\hline ENMAX & $14.6 \%$ & $13.9 \%$ & $13.5 \%$ & $13.4 \%$ & $11.2 \%$ & $17.0 \%$ \\
\hline TransAlta & $14.9 \%$ & $15.9 \%$ & $16.8 \%$ & $12.8 \%$ & $12.7 \%$ & $14.0 \%$ \\
\hline TransCanada & $20.0 \%$ & $19.0 \%$ & $18.4 \%$ & $18.1 \%$ & $17.9 \%$ & $16.5 \%$ \\
\hline Other & $30.0 \%$ & $29.9 \%$ & $30.4 \%$ & $35.5 \%$ & $36.2 \%$ & $31.2 \%$ \\
\hline
\end{tabular}

Table 2: Annual electricity production, by generation technology

\begin{tabular}{lcccccccc}
\hline Year & Coal & Cogen & CC & SC & Hydro & Wind & Biomass & Imports \\
\hline 2010 & $71.2 \%$ & $13.7 \%$ & $3.4 \%$ & $1.4 \%$ & $2.7 \%$ & $2.7 \%$ & $1.0 \%$ & $3.8 \%$ \\
2011 & $67.0 \%$ & $12.7 \%$ & $3.8 \%$ & $1.9 \%$ & $3.4 \%$ & $4.1 \%$ & $1.0 \%$ & $6.1 \%$ \\
2012 & $63.7 \%$ & $14.6 \%$ & $4.4 \%$ & $1.9 \%$ & $3.9 \%$ & $4.4 \%$ & $1.1 \%$ & $6.1 \%$ \\
2013 & $63.7 \%$ & $16.5 \%$ & $4.3 \%$ & $1.8 \%$ & $3.3 \%$ & $5.1 \%$ & $1.2 \%$ & $4.2 \%$ \\
2014 & $67.6 \%$ & $15.7 \%$ & $3.0 \%$ & $1.0 \%$ & $3.0 \%$ & $5.6 \%$ & $1.0 \%$ & $3.3 \%$ \\
2015 & $62.6 \%$ & $16.4 \%$ & $8.0 \%$ & $1.2 \%$ & $2.7 \%$ & $6.5 \%$ & $0.9 \%$ & $1.7 \%$ \\
\hline
\end{tabular}

Note: Combined Cycle (CC) and Simple Cycle (CC) 
Generators in the Alberta market are not required to make cost-based offers. As such, the offer prices selected by generators located in Alberta occasionally reflected the exercise of market power. Guidelines from the electricity market monitor, the Market Surveillance Administrator, developed in 2010 and published in 2011, provided guidance that the exercise of unilateral market power in a manner that does not impede competition would not result in enforcement action. For a thorough discussion of this and its implications, see Brown and Olmstead (2017).

Following initial submissions, both the price and quantity elements of offer blocks associated with a generating asset may be restated for any reason up to two hours before the beginning of the delivery hour. The initial requirement that the sum of offer quantities made for each generating asset be equal to its maximum capability must continue to be satisfied. A generating asset's available capability may be restated at any time, including after two hours before the beginning of the delivery hour, provided that an acceptable reason is given if it is less than its maximum capability. ${ }^{2}$

In addition to generating assets located in Alberta, offers must be submitted by traders wishing to import electric energy into Alberta in a given delivery hour. Such offers consist of a single quantity and must be made at a price of $\$ 0 / \mathrm{MWh} .{ }^{3}$ They may be submitted up to two hours before the beginning of any delivery hour and there are no technical parameters such as maximum or available capability.

Similar to producers, consumers of electric energy have the option to make explicit bids. However, because consumers have the alternative option to draw electric energy from the market without a bid, there is no practical advantage for consumers to make bids and so bids are not made. The exceptions are traders wishing to export electric energy from Alberta in a given delivery hour. Such bids are similar in every way to import offers, except that the bid price is always $\$ 999.99$ / MWh. ${ }^{4}$ The formation of market clearing prices is set out in the next section.

\subsection{Market clearing in the Alberta power pool}

For each delivery hour, the AESO takes the final offer blocks - that is, the initial offers adjusted to account for all restatements - associated with all the generating assets and imports and lists them in increasing order of offer price. To the extent that a generating asset's available capability is less than its maximum capability, the quantity difference is removed from that generating asset's offer blocks starting with the one with the highest offer price. If a generating asset is fully on outage, then all of its offer blocks would be eliminated from the list. The AESO makes other adjustments to the offer blocks as described in section 4 . The resulting ordered list of offer blocks describes the energy offers available to the AESO to provide energy if dispatched and it is called the energy market merit order.

Intermittent generating assets, such as those powered by wind, are treated differently and are not dispatched in the same way as other generators, although changes in the level of wind generation may impact the timing of other dispatches.

Since consumers generally do not submit explicit bids to the market, there is no demand schedule aside from exports. Instead, consumers make their decision to consume or not based on their expectations of price.

2. The restatement of offers is governed by ISO Rule 203.3, Energy Restatements. See Alberta Electric System Operator (2014).

3. Importers must form expectations of the pool price that will clear the market and they will be paid if they obtain an import schedule.

4. Similarly to importers, exporters must form expectations of the pool price that will clear the market and they will pay if they obtain an export schedule. 
Imports and exports for a given delivery hour are scheduled before the beginning of the delivery hour in order to allow transactions to be coordinated between neighbouring jurisdictions. This is why imports and exports are priced the way they are; they are not considered to be dispatchable during the delivery hour for economic reasons.

In order to clear the market, the AESO dispatches electric energy from the energy market merit order until supply balances demand. The relevant offers associated with intermittent generating assets are dispatched to the extent that they are physically able to produce given prevailing environmental conditions. The last offer block dispatched sets the market price at that time (in each minute) and is called the system marginal price (SMP). As the delivery hour progresses, the AESO may need to dispatch up or down the energy market merit order to account for changes in demand or availability of generation capacity. For instance, outages will occur unexpectedly and wind production changes. As such, the SMP may change throughout the delivery hour. The time-weighted average of SMPs in each delivery hour is called the pool price. This is the uniform price used for hourly settlement of all transactions in the energy market in the delivery hour.

\subsection{Information availability in the power pool}

Between July 13, 2000 and May 18, 2017, the prices and quantities of each offer to supply energy in the previous hour were published in the HTR about 5 to 10 minutes after the end of each hour. The HTR provided the (i) offers ${ }^{5}$ as submitted by noon on the day before the delivery hour and (ii) final offers as of the beginning of the delivery hour. The offers in the HTR were anonymous; that is, the generating asset associated with the offer was not included.

As noted above, offers may be restated for any reason up to two hours before the beginning of the delivery hour. This means that, as illustrated in Figure 1, the last time that offers for delivery in delivery hour $\mathrm{t}$ may be restated for economic reasons is just before the end of delivery hour $\mathrm{t}$ minus 3. The last version of the HTR that is available at that time is the one associated with delivery hour $\mathrm{t}$ minus 4 .

In addition to the HTR, the AESO is required by law to publish the full details of offers for each delivery hour 60 days after the delivery hour. ${ }^{6}$ As a result, each day the AESO publishes 24 supply curves for the 24 hourly auctions that occurred for the delivery of energy 60 days earlier. ${ }^{7}$ It is our view that, while this remains a matter for further research, the information contained in this document is too far out of date to have a significant effect on the offer strategies of market participants.

Figure 1: Offer submission timeline

$\begin{array}{cccccc}\text { Offers for } & \text { Offers for } & \text { HE 10 } \\ \text { Close of offer restatements } \\ \text { for delivery in HE10 }\end{array}$

5. Each offer includes both a price and quantity available at that price

6. See section 6 of the Fair, Efficient and Open Competition Regulation

7. This report is called the "Merit Order Snapshot Report-Energy". In addition to providing the price and quantity associated with each offer block, this report also indicates the identity of the firm (or firms) that has economic control over the block. 


\section{LITERATURE REVIEW}

\subsection{Analytical framework for considering the effect of information on competition}

The supply function equilibrium model developed by Klemperer and Meyer (1989) was adapted for application to electricity markets by Green and Newbery (1992), Bolle (1992), and Wolak (2003). The model assumes a non-cooperative game in which a producer's optimal offer strategy is one that maximises profit by offering prices and quantities for its entire portfolio conditional on its competitors offering optimally and the level of demand. Useful reviews of the SFE model and support for its application to electricity markets are provided by Holmberg and Newbery (2010) and Vives (2011).

Applications of the model have been used to test whether market outcomes are consistent with non-cooperative or collusive behaviour. Existing empirical work includes Wolak (2003), which finds that explanations involving collusive behaviour are unnecessary to explain prices increases in California's electricity market during the California energy crisis during the period from 1998 to 2000, and Sweeting (2007), which finds evidence to support tacit collusion in England and Wales' electricity market during the period from 1995 to 2000 .

The supply function equilibrium model is a static game that does not allow interaction between different periods of the game. An important practical question is whether some learning may occur or be required in order for producers to develop an optimal offer strategy in the absence of perfect information. If so, it is an important matter of market design whether learning should be facilitated by providing information about competitors' offers and the level of demand.

Regarding liberalised electricity markets specifically, Holmberg and Newbery (2010) note that disclosure of offers allows producers to implement an implicit or explicit collusive strategy and conclude that disclosure should be both delayed and possibly restricted to parts of the offer curve around the clearing price. Holmberg, Par, and Wolak (2018), in the context of a static game with private cost information, conclude that increased transparency and public information about costs increases the expected degree of competition. The authors acknowledge the possibility of tacit collusion in a repeated game.

In practice, repeated interaction may reveal information about producers' strategies or forward contracting positions. For example, a producer that offers output at prices substantially greater than marginal cost indicates that their net forward contracting position is such that they would benefit from higher prices. In this case, there is the possibility that even in the absence of an implicit or explicit coordinated strategy the sharing of offer information could further enhance the non-cooperative exercise of market power.

In most liberalised electricity markets, information on forecast and historical demand is commonly available but information about current or recent producer offer strategies is not. The contribution of this paper is to examine whether or not the release of such offer information should continue to be restricted or whether information release is warranted. We do not present a formal model of strategic behaviour that seeks to attribute impacts to either collusive behaviour or an increase in the effectiveness of unilateral behaviour. The contribution of this paper is to provide empirical evidence as to whether, in the context of a repeated hourly auction such as the Alberta electricity market, the publication of recent offer information results in higher, lower or no impact on market prices.

The empirical approach used in this paper bares similarities to the literature on event studies used to examine the impact of informational changes on stock market events (Fama et al., 1969; 
Kothari and Warner, 2007). Such studies construct an alternate set of returns, a counterfactual, that would have occurred absent an informational event.

\subsection{Existing analysis of the Historical Trading Report}

Brown, Eckert, and Lin (2018) examine the interaction among producers in the Alberta electricity market. The authors use an econometric methodology to show that certain producers respond to the lagged offer prices of other producers in a manner consistent with revelation of anonymized offer information contained in the HTR. Based in part on analysis contained in Market Surveillance Administrator (2013), the paper suggests that producers are able to identify rivals and differentiate their respective responses to them.

Brown and Eckert (2019) employ an econometric methodology and data for the year 2013 to consider whether the observed offer behaviour by certain firms in the Alberta electricity market was consistent with unilateral maximization of expected profit. The results indicate that some of these firms could have raised their expected profit by unilaterally deviating from their observed offers, suggesting that market outcomes may be inconsistent with non-cooperative competition.

Notably, data that are publicly available, including those used in the two analyses above, do not include information related to when an offer is restated. When considering what effect the publication of the HTR may have on market prices, this information is of critical importance because it allows offer restatements made before the HTR was released, which could not have been affected by the HTR, to be distinguished from offer restatements made after the HTR was released, which may have been affected by the HTR.

\section{DATA AND STUDY PERIOD}

As stated above, the HTR provided the (i) offers as submitted by noon on the day before the delivery hour and (ii) final offers as of the beginning of the delivery hour. Other information about offers is known but is not publicly available, in particular information about the times at which restatements were made. This paper uses a confidential database of all initial offers and restatements (changes to offers that have already been made) made by generators in Alberta during the period 2010 to 2015.

Since these data have never been made public, the creation of this database was necessary in order to construct the market price that would have occurred had restatements that were made after the publication of the final HTR not been made. The AESO does not operate a pre-dispatch market process in a manner comparable to many other jurisdictions and as a result it does not have to create merit orders for this purpose. Creation of the dataset presented a number of practical difficulties. Among these is that raw offers for specific generating units include capacity from those units that was designated to provide operating reserves, which is removed from the highest price offer block to determine a unit's actual availability in the energy market, and capacity used to provide Dispatch Down Service, a product unique to the Alberta electricity market which is intended to compensate for the effect of the AESO directing out-of-market generation to occur to handle local transmission constraints, is removed from the lowest price offer block.

This paper considers a six-year study period from 2010 to 2015; a total of 52,584 hours. This time period was chosen for a number of reasons. Regarding the beginning of the study period, information prior to late 2007 contained a different definition of available and maximum capability and between late 2007 and mid-2009 there were a number of problems associated with dispatch 
tools and the recording of merit order data. As a result, this paper does not consider data for this period of time. ${ }^{8}$ Regarding the end of the study period, there was an important structural change to the Alberta electricity market on January 1, 2016 that had a substantial impact on offer behaviour. Specifically, this is the date on which the virtual divestiture scheme associated with a set of Power Purchase Arrangements that was enacted as part of the deregulation process began to unravel. ${ }^{9}$ The result was that a government entity, the Balancing Pool, quickly found itself with control of almost $30 \%$ of Alberta's generation capacity for the next several years. For this reason, the time period after 2015 has been excluded from this study. Finally, the authors decided to limit the time period to full years to ensure that the seasons were balanced and, as a result, the six calendar years from 2010 to 2015 were selected for the study.

\section{EMPIRICAL STRATEGY}

The methodology used to consider the effect of the HTR on market prices is to take observed market prices and compare them to those that would have resulted if restatements involving changes to prices following the publication of the final HTR did not occur.

The empirical strategy has two elements. First, a counterfactual supply curve that reflects the absence of the HTR is constructed. Second, following Brown and Olmstead (2017), a residual market demand curve is estimated using reduced-form approaches to separately estimate hourly (i) price-responsive demand for a subset of large consumers in Alberta and (ii) import supply from neighbouring jurisdictions. The combination of these elements allows us to estimate the counterfactual market prices and quantities that would have prevailed in the absence of the HTR.

\subsection{Counterfactual supply curve}

While counterfactual offer prices cannot be directly observed, using the confidential database of offer restatements discussed above, they can be estimated. Since all restatements are timestamped, those restatements that were made after the most recent HTR was published can be identified and offers as they existed before its publication can be recreated. A counterfactual market supply curve based on these offers can then be constructed and used to determine a counterfactual market clearing price (and quantity of consumption).

The method employed to construct the counterfactual removes only those restatements

where offer prices were changed. Restatements where the available capability but not offer price was changed are not removed as these represent reductions or increases in available energy and are required by the market rules when physical conditions at generators change (e.g., outages). The method of identifying which offers are influenced by the HTR is subject to several limitations because the reason why a producer restated a specific offer cannot be observed. First, as only offers after the most recent HTR was published are eliminated, whether previous HTR publications are the cause of earlier restatements is not considered. Second, it is not certain whether the restatements that have been removed would have occurred even in the absence of the publication of the HTR.

The first limitation may result in under-estimating the impact associated with the HTR. The second limitation would be particularly problematic if the market participants most likely to exercise market power did so only through a single restatement at the last possible time. If this were true,

8. Market Surveillance Administrator (2009).

9. See Olmstead and Ayres (2014) for additional background information about the Alberta electricity market, including the Power Purchase Arrangements. 
this methodology may over-estimate the impact of the HTR. However, while price restatements become more frequent up to two hours before the beginning of the delivery hour, after which no further changes in prices are allowed, a study conducted by the AESO indicates that the vast majority occur before the final HTR report is published..$^{10}$ Further, a study by the Market Surveillance Administrator found that $84 \%$ of the price restatements in 2011 were made by the largest five generators, which controlled about $70 \%$ of the generation capacity. ${ }^{11}$

From this it is concluded that those generators that were most likely to be able to profitably exercise market power do not restate only after the final HTR has been released. Hence, the removal of restatements according to the methodology set out above does not remove the effect of updated expectations about changes in market conditions that occurred since offers were made initially in the day-ahead period and before the final HTR was published.

The use of this empirical approach to identify the impact of the HTR's publication amounts to assuming the offers as they existed prior to the publication of the HTR reflect all known information about the delivery hour as well as the various firms' intentions to profit maximize in the delivery hour and their expectations of their competitors to do the same. As such, the restatements made in the one-hour period before the gate-closure are assumed to be due to the revelation of information thereafter, particularly the information contained in the HTR about the most recent choices of competitors. Of course, other information about the delivery hour may become known at the same time. It is assumed this information does not systematically affect producer offer behaviour.

The procedure implemented in this paper to estimate the counterfactual supply curve is as follows:

1. Record the observed supply curve from which each observed SMP was taken and record the observed amount of production that was necessary to satisfy demand at that time.

2. Identify all restatements of offers for delivery in the delivery hour that occurred in the last hour before gate-closure.

3. For each identified restatement, change the offer on the observed supply curve for the delivery hour to what it was before the restatement was made. Including the set of offers that were not restated, this is the set of counterfactual offers. Total offer quantities for each generator remain unchanged although may be redistributed to different price levels as a result of the restatement.

4. Sort the counterfactual offers in ascending order of offer price. This is the counterfactual supply curve.

\subsection{Residual market demand curve estimation}

Consumer behaviour is assumed to be independent of any effects associated with the HTR. However, to the extent that market supply would have been different in the absence of the HTR, the market may clear at a different point on the demand curve. While demand for electricity is generally observed to be highly price inelastic, there is some degree of price responsiveness on the demand-side of the market. The two main sources of this price-responsiveness are (i) large consumers located within Alberta for which electricity is a major input cost and (ii) traders who schedule imports and exports.

10. Alberta Electric System Operator (2012), section 5.2

11. Market Surveillance Administrator (2012), section 2.3.1, and Table 1 above. 


\subsubsection{Estimation of price-responsive industrial demand within Alberta}

The demand curve is not observed. Following Brown and Olmstead (2017), price-responsive industrial demand within Alberta is modelled as a linear-log function of the observed market price, $p_{t}$ :

$$
\begin{aligned}
Q_{t}= & \theta_{0}+\theta_{1} \ln p_{t}+\theta_{2} \ln p_{t}^{N G}+\theta_{3} \text { Weekday }_{t}+\theta_{4} \text { Holiday }_{t}+\phi h\left(\text { Temp }_{A B, t}\right) \\
& +\sum_{h=2}^{24} \omega_{h} \text { Hour }_{h t}+\sum_{m=2}^{12} \gamma_{m} \text { Month }_{m t}+\sum_{y=2011}^{2015} \psi_{y} \text { Year }_{y t}+\eta_{t}
\end{aligned}
$$

where $\ln p_{t}^{N G}$ is the natural $\log$ of the price of natural gas, $h\left(\operatorname{Temp}_{A B, t}\right)$ is a non-linear function of temperature variables for Alberta, and Weekday ${ }_{t}$, Holiday $_{t}$, Hour $_{h t}$, Month $_{m t}$, and Year ${ }_{y t}$ are indicator variables for weekdays or not, provincial holidays in Alberta or not, hour-endings, month and year in the data set, respectively. ${ }^{12}$ The covariates contain various demand shifters to account for nonprice related demand factors and the natural gas price controls for fuel substitution.

Estimating the relationship between the price of electricity and the quantity demanded is difficult because demand is impacted by various factors other than price, shifting the demand curve along the supply curve. This creates potential correlation between the price variable and the error term. This endogeneity concern is alleviated by finding instrumental variables (IV) for the price of electricity. First, the common approach of using lagged prices as the exclusive IVs is adopted (e.g., see Lijesen, 2007; Aroonruengsawat, Auffhammer, and Sanstad, 2012). Second, supply shifters are used as IVs that impact demand only through their impact on the electricity price. The exclusive instrument used is the capacity supply availability that reflects the sum of the available electricity generation capacity within Alberta and the import transmission capacity limits.

To estimate the price-responsive industrial demand function, the paper utilises confidential meter data held by the AESO for various large industrial consumers in Alberta that represent up to $8 \%$ of hourly dispatch. These customers are firms primarily in the pulp, paper, forestry, and petrochemical sectors.

Table 8 provides detailed estimates of the price-responsive demand function. The coefficients imply average price-elasticities of demand of -0.28 and -0.19 for the lagged price and supply shifter IVs, respectively. The results from the lagged price IV model are used in the subsequent

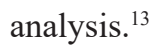

12. The temperature variables used in the analysis for Alberta (Calgary and Edmonton), British Columbia-Montana (Vancouver), and Saskatchewan (Saskatoon) are modelled as quadratics for cooling degree hours (CDH), when the hourly temperature is greater than 18.33 degrees Celsius (65 degrees Fahrenheit), and heating degree hours (HDH), when the hourly temperature is less than 18.33 degrees Celsius. The terms $\mathrm{CDH}$ and $\mathrm{HDH}$ are used instead of the more common cooling and heating degree day (CDD and HDD) to highlight that the variables used are constructed on an hourly rather than daily basis. These data are accessed through Environment and Climate Change Canada: Historical Climate Data: Historical Data. The results of the analysis are robust to the consideration of higher degree polynomials on the temperature variables and alternative large cities in each jurisdiction.

13. Given the likelihood that the price is endogenously determined, the analysis uses the IV estimates because they are consistent even if not necessarily efficient. Use of the price coefficient from the lagged price regression is consistent with the approach taken in Brown and Olmstead (2017). Nevertheless, all of the results that follow are robust to using the regression coefficient from either the supply shifter IV regression or the OLS regress. This is because the magnitudes of the coefficients are similar and much smaller than the price-responsive effect related to import supply. 


\subsubsection{Estimation of import supply}

The import supply curve is also not observed. Imports to the Alberta electricity market come from two neighbouring regions: British Columbia-Montana (BCMT) and Saskatchewan (SK). Following Brown and Olmstead (2017), an import supply function is estimated for each of the neighbouring jurisdictions as a linear-log function of the observed market price, $p_{t}$ :

$$
\begin{aligned}
Q_{j t}^{I M}= & \beta_{0 j}+\beta_{1 j} \ln p_{t}+\beta_{2 j} \text { Weekday }_{t}+\beta_{3 j} \text { Holiday }_{t}+\alpha h\left(\text { Temp }_{j t}\right) \\
& +\sum_{h=2}^{24} \omega_{h} \text { Hour }_{h t}+\sum_{m=2}^{12} \gamma_{m} \text { Month }_{m t}+\sum_{y=2011}^{2015} \psi_{y} \text { Year }_{y t}+\varepsilon_{t}
\end{aligned}
$$

where $h\left(\right.$ Temp $\left._{j t}\right)$ is a non-linear function of temperature variables in neighbouring region $j$ (i.e., not temperatures in Alberta), and Weekday ${ }_{t}$, Holiday $_{t}$, Hour $_{h t}$, Month $_{m t}$, and Year ${ }_{y t}$ are indicator variables for weekdays or not, provincial holidays in Alberta or not, hour-ending, month and year in the data set, respectively. The time period-based indicator variables control for systematic variation of demand and input supply shocks.

The price of electricity is affected by the quantity of imports supplied and is therefore endogenously determined. Following Mansur (2008), an instrumental variables approach is used to address the endogeneity of price, where the exclusive instruments are hourly temperatures in Alberta. Measures of temperatures in Alberta are valid instruments because they affect the prevailing demand conditions in Alberta and so impact the market price in Alberta $\left(p_{t}\right)$. However, the temperature variation in Alberta only impacts the import quantity through its impact on $p_{t}$. The instruments selected are the same as in Brown and Olmstead (2017).

Data on imports are publicly available 60 days after the delivery hour on the website of the AESO. ${ }^{14}$

Table 9 provides detailed estimates of the import supply functions. The coefficients imply average price-elasticities of imports of 0.61 and 0.42 for British Columbia-Montana and Saskatchewan, respectively.

\subsection{Counterfactual market equilibrium}

The counterfactual methodology finds a counterfactual SMP for each of the observed SMPs. To simplify the analytical approach, it is assumed that the times at which the observed SMP changes are the only times at which the counterfactual SMP may change. ${ }^{15}$

The observed SMP is the price at the intersection of the observed supply curve and the residual demand curve that incorporates the effect of both (i) price-responsive industrial demand in Alberta and (ii) import supply from neighbouring jurisdictions. As illustrated generically in Figure 2 , the counterfactual SMP is the price at the intersection of the counterfactual supply curve and the same residual demand curve. The counterfactual pool price for a delivery hour is the time-weighted average of the counterfactual SMPs within the delivery hour.

14. To access these data, go to ets.aeso.caets.aeso.ca -> Historical -> Merit Order Snapshot (Energy).

15. For the time period during which a particular SMP prevails, the methodology assumes that both the supply and demand curves are constant. Similarly, the counterfactual supply curve is constant as well. As a result, the times at which the SMPs change are held constant. In practice, Alberta's electricity market, unlike most other liberalised electricity markets, does not rely on a multi-period optimization algorithm to determine the timing of dispatch. Dispatch timing is reliant upon the judgement of individual system coordinators that in turn may be influenced by factors that are not easy to observe. In effect, the methodology here holds these decisions constant. 
Figure 2: The observed and counterfactual market equilibria

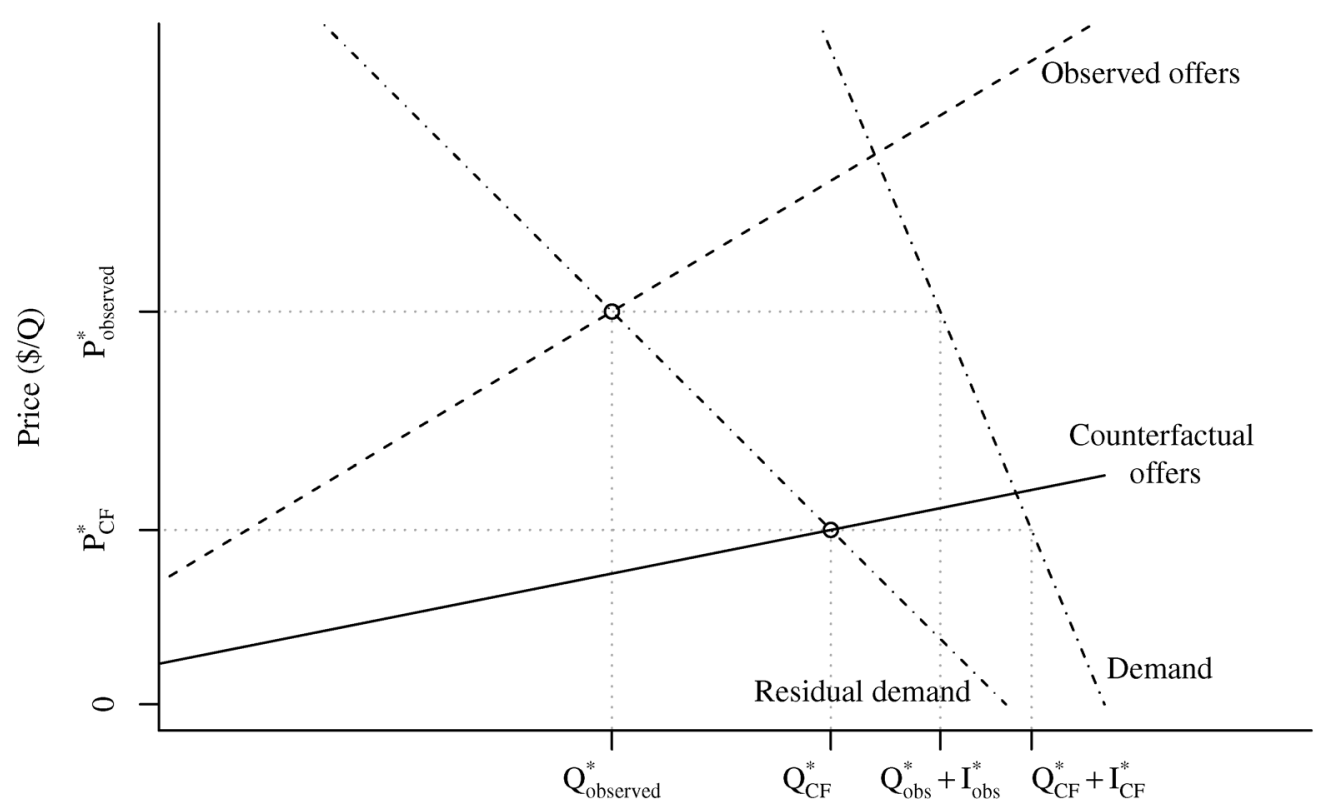

Quantity

The restatement impact is defined to be the counterfactual pool price less the observed pool price. If the restatement impact is positive in a delivery hour, then the effect of restatements was to raise the pool price above what it otherwise would have been. If, on average, the restatement impact is positive, then there is evidence that the information contained in the HTR facilitates learning that allows for the increased exercise of unilateral market power.

\section{COUNTERFACTUAL RESULTS}

To clarify the mechanics of the information publication and offer restatement process, the evolution of offers in a single, specific delivery hour is discussed in detail. Systematic application to all 52,584 hours in the data set follows thereafter.

\subsection{An illustrative example: The electricity market on September 6, 2011, hour-ending 10}

The hour-ending 10 settlement interval runs from 9 to 10 a.m. and therefore any offer price restatements must be submitted before $7 \mathrm{a} . \mathrm{m}$. The offers for hour-ending 10, as they were at 6 and 7 a.m., are illustrated in Figure 3. Specifically, at 6 a.m. there were $171 \mathrm{MW}$ of offers for delivery in hour-ending 10 made at prices between $\$ 100 / \mathrm{MWh}$ and $\$ 986 / \mathrm{MWh}$, including none at any prices between $\$ 500 / \mathrm{MWh}$ and $\$ 986 / \mathrm{MWh}$, exclusive.

The HTR for hour-ending 6 was published between 6:05 and 6:10 a.m. and is illustrated in Figure 4. There were $363 \mathrm{MW}$ between $\$ 100 / \mathrm{MWh}$ and $\$ 620 / \mathrm{MWh}$, a $43 \mathrm{MW}$ block at $\$ 955.65 /$ MWh, and two $101 \mathrm{MW}$ offers at $\$ 986 / \mathrm{MWh}$ and $\$ 987 / \mathrm{MWh}$. This made clear the relatively steep shape of the residual demand curve faced in that hour by each generator, including the $\$ 335.65$ / MWh wide price band with no offers. 
Figure 3: Offers for hour-ending 10 on September 6, 2011

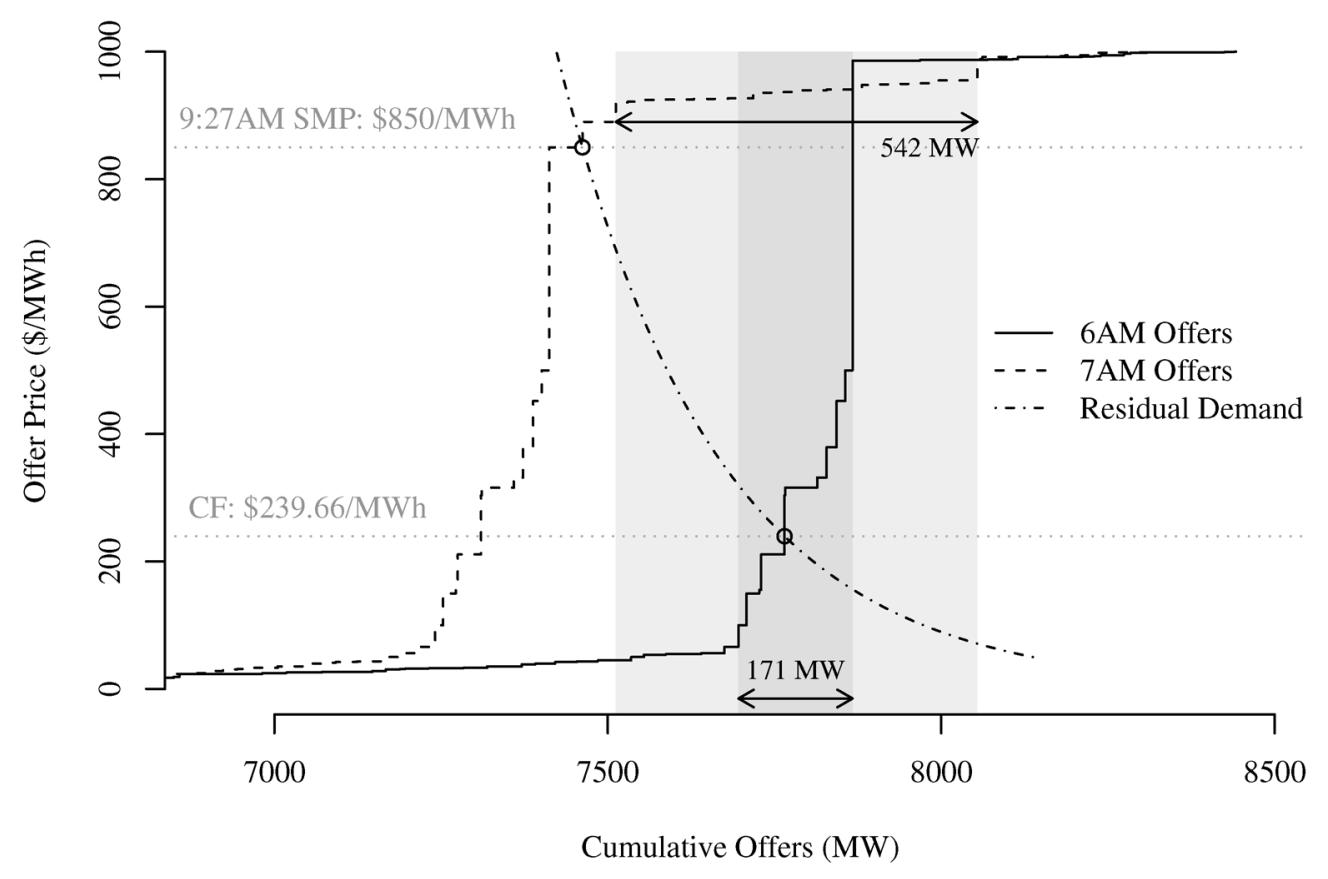

Figure 4: The HTR for hour-ending 6 on September 6, 2011.

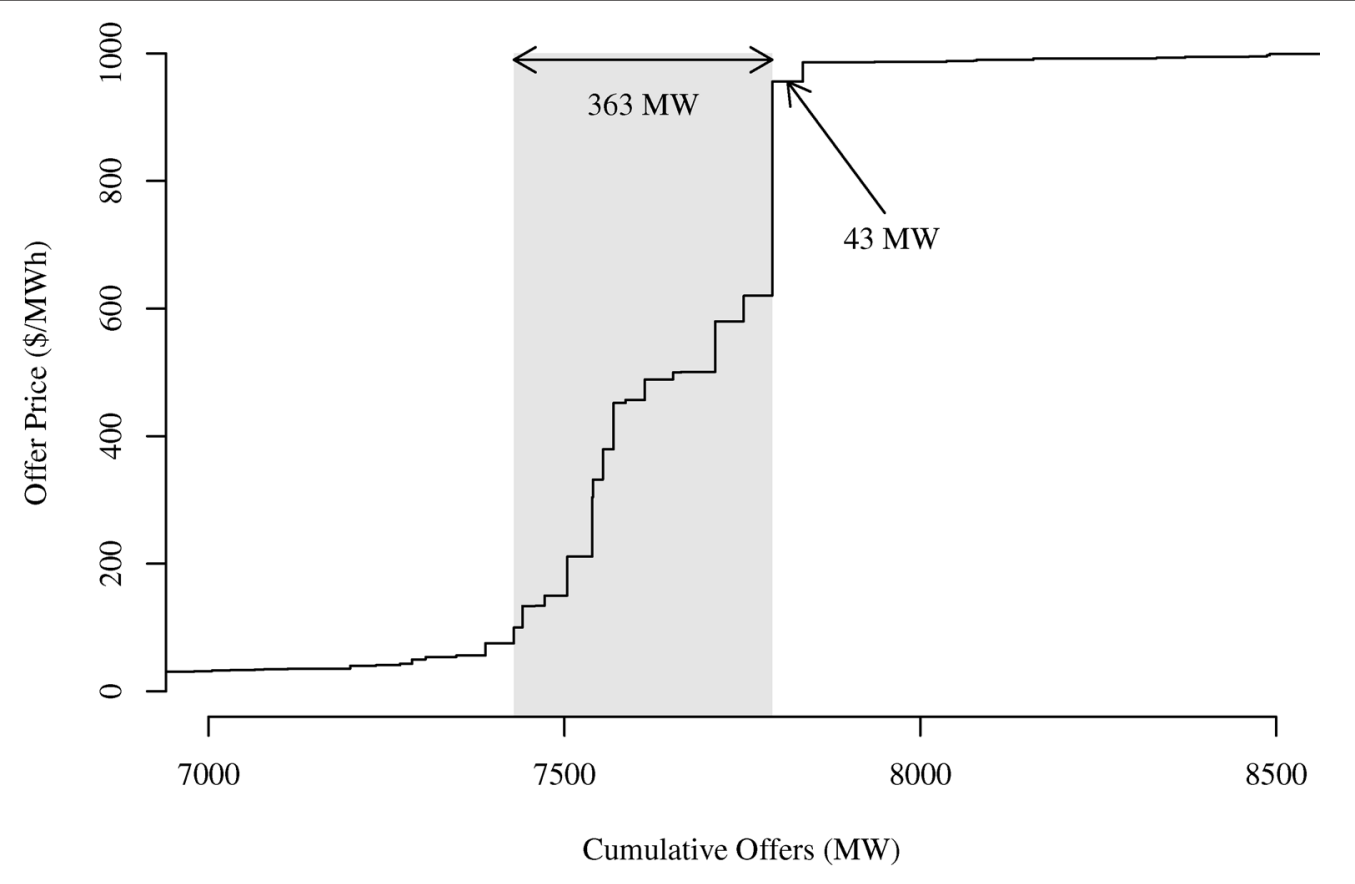

Table 3 reports the complete set of offer restatements made between 6 and 7 a.m. for delivery in hour-ending 10. A total of $542 \mathrm{MW}$ of offers were restated to prices between $\$ 920.56 / \mathrm{MWh}$ and $\$ 955.01 / \mathrm{MWh}$ and two $50 \mathrm{MW}$ offers were restated at prices $\$ 850 / \mathrm{MWh}$ and $\$ 890 / \mathrm{MWh}$ (each 


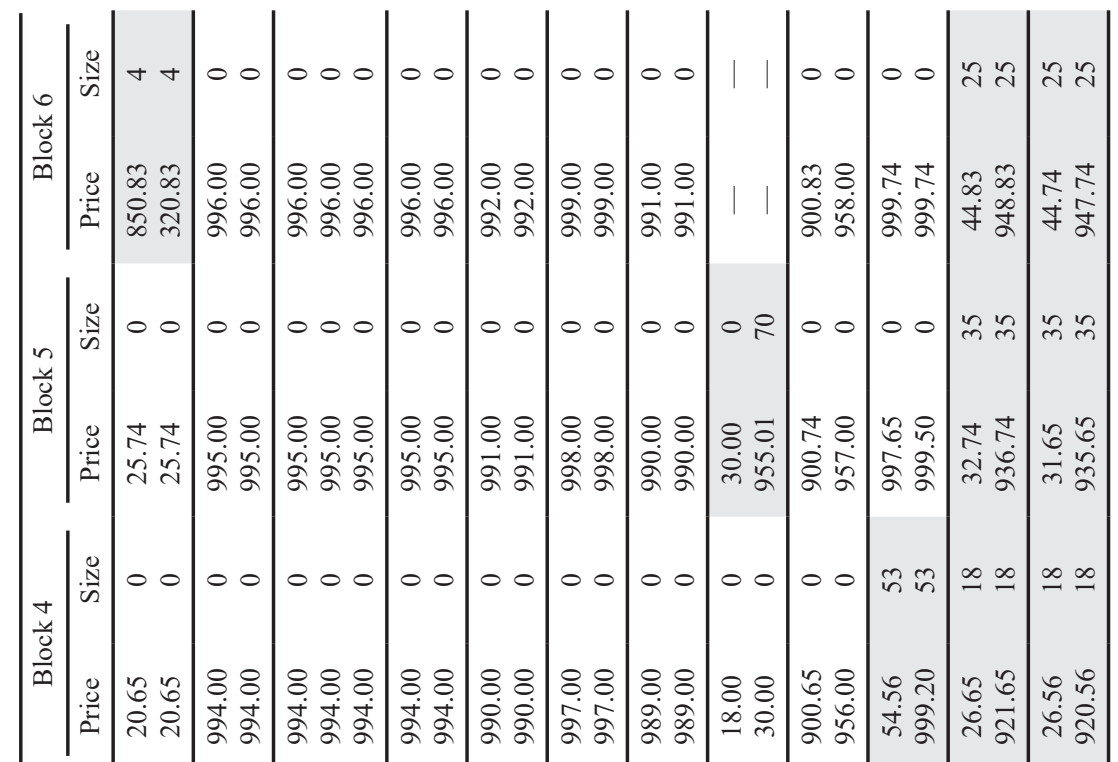

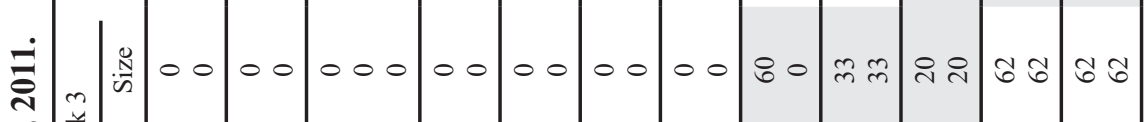

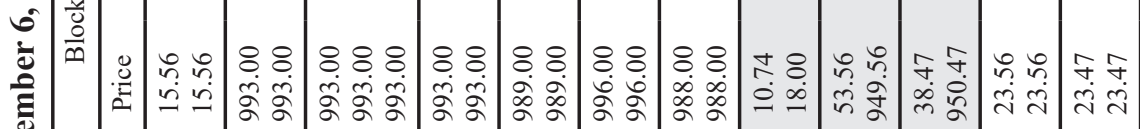

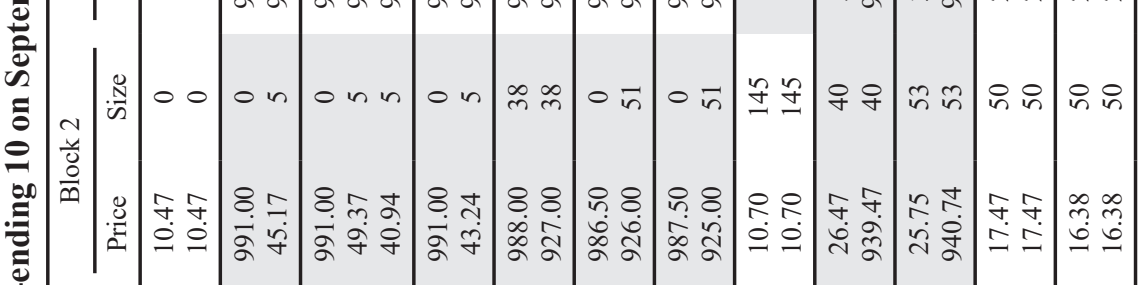

章

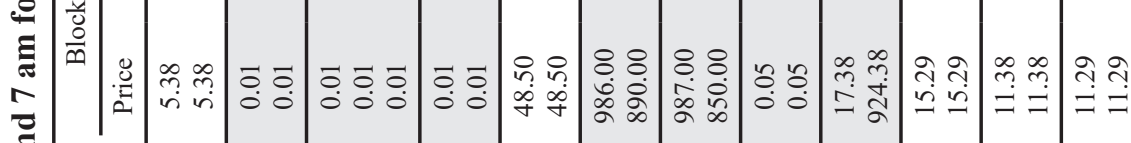

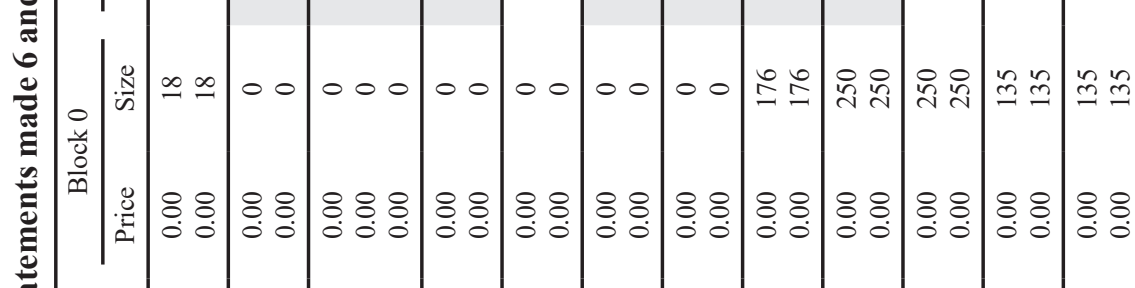

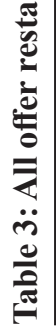

All rights reserved. Copyright $(C 2020$ by the IAEE. 
of which was part of one of the $101 \mathrm{MW}$ offers referred to above made at prices $\$ 986 / \mathrm{MWh}$ and \$987/MWh), respectively.

The hour-ending 6 HTR revealed a limited number of offers between $\$ 100 / \mathrm{MWh}$ and $\$ 620 / \mathrm{MWh}$, and none at all above this range until $\$ 955.65 / \mathrm{MWh}$. This made clear the shape of the residual demand curve faced in that hour by each generator, including the approximately $\$ 335 /$ MWh wide price band with no offers. In the approximately 50 minutes that followed the publication of the hour-ending 6 HTR, substantial quantities of offers for the hour-ending 10 settlement interval - the nearest one for which the offer gate closure had not yet occurred-were restated to prices in a $\$ 34.45 / \mathrm{MWh}$ wide price band ranging from $\$ 920.56 / \mathrm{MWh}$ to $\$ 955.01 / \mathrm{MWh}$. The upper limit of this price band was $\$ 0.64 / \mathrm{MWh}$ below the upper limit of the $\$ 335 / \mathrm{MWh}$ wide price band in the hour-ending 6 HTR for which there were no offers at all.

To determine the impact of these restatements on the market price, note that in hour-ending 10 on September 6, 2011, the observed Alberta pool price settled at $\$ 848.80 / \mathrm{MWh}$ based on the sequence of observed SMPs reported in Table 4 that ranged from $\$ 451.97 / \mathrm{MWh}$ to $\$ 936.74 / \mathrm{MWh}$. Each of these SMP necessarily corresponds to an offer price in the observed supply curve during the delivery hour and, as a result of offer prices being locked as of two hours before the beginning of the delivery hour, an offer price at 7 a.m. for delivery in hour-ending 10 as illustrated in Figure 3.

Table 4: Observed and counterfactual SMPs, hour-ending 10 on September 6, 2011

\begin{tabular}{|c|c|c|c|c|c|c|}
\hline $\begin{array}{l}\text { Time SMP } \\
\text { set }\end{array}$ & $\begin{array}{l}\text { Number of } \\
\text { minutes }\end{array}$ & $\begin{array}{l}\text { Observed SMP } \\
\text { (\$/MWh) }\end{array}$ & $\begin{array}{c}\text { Counterfactual MP } \\
\text { (\$/MWh) }\end{array}$ & $\begin{array}{l}\text { Impact } \\
(\$ / M W h)\end{array}$ & $\begin{array}{c}\text { Observed dispatch } \\
\text { (MW) }\end{array}$ & $\begin{array}{l}\text { Counterfactual } \\
\text { dispatch (MW) }\end{array}$ \\
\hline 09:00 & 3 & 451.97 & 124.98 & 326.99 & 7,401 & 7,708 \\
\hline 09:03 & 1 & 500.00 & 144.88 & 355.13 & 7,412 & 7,708 \\
\hline 09:04 & 3 & 850.00 & 239.66 & 610.34 & 7,462 & 7,765 \\
\hline 09:07 & 5 & 921.65 & 315.74 & 605.91 & 7,548 & 7,804 \\
\hline 09:12 & 1 & 924.38 & 331.84 & 592.54 & 7,578 & 7,823 \\
\hline $09: 13$ & 5 & 936.74 & 673.63 & 263.11 & 7,788 & 7,867 \\
\hline 09:18 & 3 & 926.00 & 451.97 & 474.03 & 7,680 & 7,852 \\
\hline $09: 21$ & 4 & 924.38 & 331.84 & 592.54 & 7,578 & 7,823 \\
\hline $09: 25$ & 2 & 890.00 & 308.07 & 581.93 & 7,512 & 7,766 \\
\hline $09: 27$ & 33 & 850.00 & 239.66 & 610.34 & 7,462 & 7,765 \\
\hline Full Hour & 60 & 848.80 & 295.43 & 553.37 & 7,515 & 7,782 \\
\hline
\end{tabular}

The level of dispatch while the observed SMP prevailed is the sum of all volume offered at prices less than or equal to the observed SMP. The counterfactual SMP is then found by:

1. Drawing residual demand curve, with the method as described in section 5.3, such that it intersects through the observed market equilibrium.

2. Reading up the counterfactual supply curve, until it intersects the residual demand curve, and recording the market price and dispatch. The level of market demand and the counterfactual SMP are recorded in Table 4.

3. Finally, the counterfactual pool price is calculated as a time-weighted average of counterfactual SMPs.

Specifically illustrated in Figure 3, in the thirty-three minute long period from 9:27 to 10:00 a.m. the observed SMP was $\$ 850 / \mathrm{MWh}$, with market dispatch equal to 7,462 MW, whereas the counterfactual SMP was $\$ 239.66 / \mathrm{MWh}$. Over the whole delivery hour, counterfactual SMPs ranged from $\$ 124.98 / \mathrm{MWh}$ to $\$ 673.63 / \mathrm{MWh}$. The counterfactual pool price is found to be $\$ 295.43 /$ $\mathrm{MWh}$, which is $65 \%$ lower than the observed pool price of $\$ 848.80 / \mathrm{MWh}$. 
In other words, the effect of offer price restatements following the publication of the HTR that revealed that in the most recently ended delivery hour there was a limited number of offers between $\$ 100 / \mathrm{MWh}$ and $\$ 620 / \mathrm{MWh}$, and none at all above this range until $\$ 955.65 / \mathrm{MWh}$, was to raise the pool price by about 3 times or $187 \%$.

\subsection{The six-year period from 2010 to 2015 : 52,584 hours}

Table 5 reports the average observed and counterfactual prices for the 52,584 hours in the six-year period from 2010 to 2015 as a whole and annually. Table 6 reports the average restatement impact, as well as statistics about the fraction of hours in which the restatement impact was zero, positive, or negative. The results of Wald tests that consider whether the average restatement impact is positive are also reported for each time period. Further details on the covariance matrix assumptions are provided in section 7.

Table 5: Summary statistics regarding the observed and counterfactual pool prices

\begin{tabular}{lcccccc}
\hline & & \multicolumn{2}{c}{ Observed pool price $(\$ / M W h)$} & & \multicolumn{2}{c}{ Counterfactual pool price $(\$ / M W h)$} \\
\cline { 3 - 3 } \cline { 6 - 7 } Year & $\mathrm{N}$ & Mean & Sd. Dev & & Mean & Sd. Dev \\
\hline $2010-2015$ & 52,584 & 59.06 & 132.74 & & 56.58 & 127.26 \\
2010 & 8,760 & 50.88 & 88.74 & & 50.09 & 87.49 \\
2011 & 8,760 & 76.22 & 164.21 & & 73.82 & 160.12 \\
2012 & 8,784 & 64.32 & 148.87 & & 62.52 & 146.24 \\
2013 & 8,760 & 80.19 & 169.50 & & 76.06 & 163.63 \\
2014 & 8,760 & 49.42 & 104.47 & & 46.43 & 92.74 \\
2015 & 8,760 & 33.34 & 86.51 & & 30.53 & 74.71 \\
\hline
\end{tabular}

The average observed and counterfactual pool prices over the six-year period are $\$ 59.06$ / $\mathrm{MWh}$ and $\$ 56.58 / \mathrm{MWh}$, respectively. The average price difference for the six-year period is $\$ 2.48 /$ $\mathrm{MWh}$, which is equal to $4.2 \%$ of the average observed pool price. This means that the average effect on the pool price of the restatements that occur after the final HTR is published is to raise the pool price by $\$ 2.48 / \mathrm{MWh}$, or $4.2 \%$. This result is statistically significant with greater than $99 \%$ confidence. The quantity weighted average price difference for the six-year period is slightly higher $(\$ 2.67 / \mathrm{MWh})$, since, as explored further in section 7.2, price increases generally occur during higher demand hours.

The average observed pool price was greater than the counterfactual pool price in each of the six years of the study period. The annual average price difference ranged from a minimum of $1.6 \%$ in 2010 to a maximum of $8.4 \%$ in 2015 . The average price difference is statistically greater than zero at a $95 \%$ confidence in all years.

Table 6: Summary statistics regarding the restatement impact

\begin{tabular}{lcccccccc}
\hline Year & $\begin{array}{c}\text { Mean } \\
(\$ \mathrm{MWh})\end{array}$ & $\begin{array}{c}\text { Std.dev. } \\
(\$ / \mathrm{MWh})\end{array}$ & $\begin{array}{c}\text { Diff. }(\% \text { of } \\
\text { observed })\end{array}$ & $\%>0$ & $\%=0$ & $\%<0$ & $\begin{array}{c}\text { 95\% conf. interval } \\
\text { of the mean }\end{array}$ & $\begin{array}{c}\text { Wald test H0: } \\
\text { mean=0 (p-value) }\end{array}$ \\
\hline $2010-2015$ & 2.48 & 31.39 & $4.2 \%$ & $14 \%$ & $63 \%$ & $23 \%$ & 1.96 to 3.01 & 0.0000 \\
2010 & 0.79 & 13.70 & $1.6 \%$ & $9 \%$ & $72 \%$ & $19 \%$ & 0.09 to 1.50 & 0.0279 \\
2011 & 2.40 & 29.87 & $3.1 \%$ & $13 \%$ & $66 \%$ & $21 \%$ & 1.35 to 3.44 & 0.0000 \\
2012 & 1.79 & 22.74 & $2.8 \%$ & $16 \%$ & $63 \%$ & $21 \%$ & 1.19 to 2.40 & 0.0000 \\
2013 & 4.13 & 34.53 & $5.1 \%$ & $19 \%$ & $57 \%$ & $24 \%$ & 2.84 to 5.42 & 0.0000 \\
2014 & 2.99 & 39.76 & $6.0 \%$ & $14 \%$ & $57 \%$ & $29 \%$ & 1.15 to 4.83 & 0.0015 \\
2015 & 2.81 & 39.19 & $8.4 \%$ & $12 \%$ & $63 \%$ & $26 \%$ & 1.26 to 4.36 & 0.0004 \\
\hline
\end{tabular}


The results also indicate that the observed and counterfactual pool prices are the same in $63 \%$ of hours over the six-year period. This partially reflects the fact that restatements may not have occurred after the final HTR was published. The restatement impact indicates prices are higher (positive) in 14\% of hours and lower (negative) in $23 \%$ of hours. Despite being fewer in number, the restatement impacts that result in higher prices are larger than those that result in lower prices and as such the average impact higher prices.

On the basis of these results, it is concluded that the effect of the publication of the HTR was to reduce the competitiveness of the Alberta electricity market. Put differently, the publication of the HTR provided information that enhanced the ability of market participants in Alberta's electricity market to unilaterally exercise market power by allowing them to learn about their competitors' offer strategies.

\subsection{The impact on the aggregate value of electricity}

The higher pool prices that resulted from the publication of the HTR raised the value of electricity that was consumed by consumers. Given that the increase in pool prices persisted over a long period of time, it is reasonable to expect that it also influenced forward prices for electricity and thus would have impacted even those customers who engaged in forward trades to hedge exposure to the pool price. Also, some consumers own generation assets. While they would therefore have hedged at least some of their exposure to the pool price, the higher pool prices that resulted from the HTR raise the opportunity cost of their consumption.

Table 7: Restatement impact on the aggregate value and quantity of electricity consumed

\begin{tabular}{|c|c|c|c|c|c|}
\hline \multirow[b]{2}{*}{ Year } & \multirow{2}{*}{$\begin{array}{l}\text { Mean impact } \\
(\$ / \mathrm{MWh})\end{array}$} & \multicolumn{2}{|c|}{ Alberta Internal Load (TWh) } & \multirow{2}{*}{$\begin{array}{l}\text { Load change } \\
\text { (GWh) }\end{array}$} & \multirow{2}{*}{$\begin{array}{l}\text { Impact on electricity } \\
\text { value (\$ millions) }\end{array}$} \\
\hline & & Observed & Counterfactual & & \\
\hline 2010-2015 & 2.48 & 458.6 & 458.7 & -114.1 & $1,139.38$ \\
\hline 2010 & 0.79 & 71.7 & 71.7 & -8.3 & 57.01 \\
\hline 2011 & 2.40 & 73.6 & 73.6 & -15.5 & 176.55 \\
\hline 2012 & 1.79 & 75.6 & 75.6 & -20.5 & 135.56 \\
\hline 2013 & 4.13 & 77.5 & 77.5 & -38.1 & 319.61 \\
\hline 2014 & 2.99 & 79.9 & 80.0 & -7.6 & 238.85 \\
\hline 2015 & 2.81 & 80.3 & 80.3 & -24.1 & 225.42 \\
\hline
\end{tabular}

Alberta Internal Load is a broad measure of demand for electricity in the Alberta market. Yearly total Alberta Internal Load, measured in TWh, is reported in Table 7 (which also reproduces the mean restatement impact from Table 5). The impact of the HTR on the aggregate value of electricity consumed in Alberta is the product of the price impact of the HTR and the Alberta Internal Load. As reported in the table, the aggregate value of electricity consumption in Alberta during the six-year period increased by approximately $\$ 1.14$ billion as a result of the publication of the HTR. ${ }^{16}$

\section{ADDITIONAL ECONOMETRIC RESULTS}

The previous section discussed the average restatement impacts in different timeframes. Beyond that, it is also of interest to understand if and how restatement impacts vary systematically with market conditions and time period.

16. Mathematically, the sum of the six annual products ( $\$ 1,153$ million) does not have to equal the single product for the whole study period ( $\$ 1,139$ million) but are quite close in value. 
With time series data, autocorrelation and heteroskedasticity is a particular concern. Durbin-Watson tests of the following linear regressions would all reject the null hypothesis that the autocorrelation of the disturbances is zero. Therefore, throughout this section, Wald tests are used to determine the significance of the estimated coefficients. The tests use heteroskedastic and autocorrelation consistent (HAC) covariance matrix estimators that are derived using Bartlett kernel weights, pre-whitening, and automatic bandwidth selection as described in Newey and West (1994).

\subsection{Supply cushion effect}

The supply cushion is defined as the quantity of available but unutilized (for energy or operating reserves) capacity in the energy market merit order. It is a simple measure of supply and demand conditions in the market. When the supply cushion is relatively large, the market has large amounts of available but unutilized generation capacity and there is unlikely that any firm will have substantial market power. Under these conditions, the market price is likely to be approximately equal to the marginal generator's marginal cost of production. The publication of information about competitors' recent offers is unlikely to change this. As a result, when the supply cushion is relatively large, the average restatement impact is likely to be close to zero. ${ }^{17}$

If the information contained in the HTR facilitates learning that allows for the increased exercise of unilateral market power, some amount of market power must exist independent of the HTR for the HTR to have any effect. As the supply cushion falls and market conditions tighten, market power is likely to appear independently of the HTR. ${ }^{18}$ Under these conditions, the average restatement impact may become positive. However, as the supply cushion reaches very low levels and converges to zero, a combination of market power, scarcity, and high marginal cost is likely to cause the market price to rise toward the market price cap. Since the information contained in the HTR is not fundamental to this outcome, the average restatement impact is also likely to fall to zero.

Thus, if the HTR has the effect of facilitating learning that allows for the increased exercise of market power, it should be expected that the average restatement impact will be zero at relatively high supply cushion levels, become increasingly positive as the supply cushion declines, and then decrease to zero again as the supply cushion converges to zero. There would be a highly non-linear relationship between the restatement impact and the supply cushion.

There is a substantial amount of noise in high frequency electricity market data. To measure the relationship between restatement impacts and the supply cushion, a set of $200 \mathrm{MW}$-wide supply cushion bins that cover the entire range of observed supply cushions is defined. Each hour in the data set is then allocated to the appropriate bin and a set of indicator variables is defined. Finally, the restatement impact is regressed on the set of supply cushion indicator variables. With the constant suppressed, the resulting coefficient and $95 \%$ confidence interval for each supply cushion bin is illustrated in Figure 5. The estimates can be interpreted as the mean restatement impact for a given supply cushion bin because the constant was suppressed.

The estimates illustrated in Figure 5 are consistent with the expectations described above about the HTR facilitating learning that allows for the increased exercise of market power. Further, the figure makes plain that the relationship between the supply cushion and restatement impact is highly non-linear.

17. Imports are not dispatchable within the delivery hour except under emergency circumstances. As a result, available but unutilized import capacity does not contribute to the supply cushion. As imports are held constant in this section, the import supply function methodology from section 5.2.2 is not employed here.

18. As explained in Brown and Olmstead (2017), as market conditions tighten, the ability for market participants to exercise market power is enhanced. The HTR was not considered in that paper. 


\section{Figure 5: 95\% confidence intervals for restatement impact by supply cushion bin}

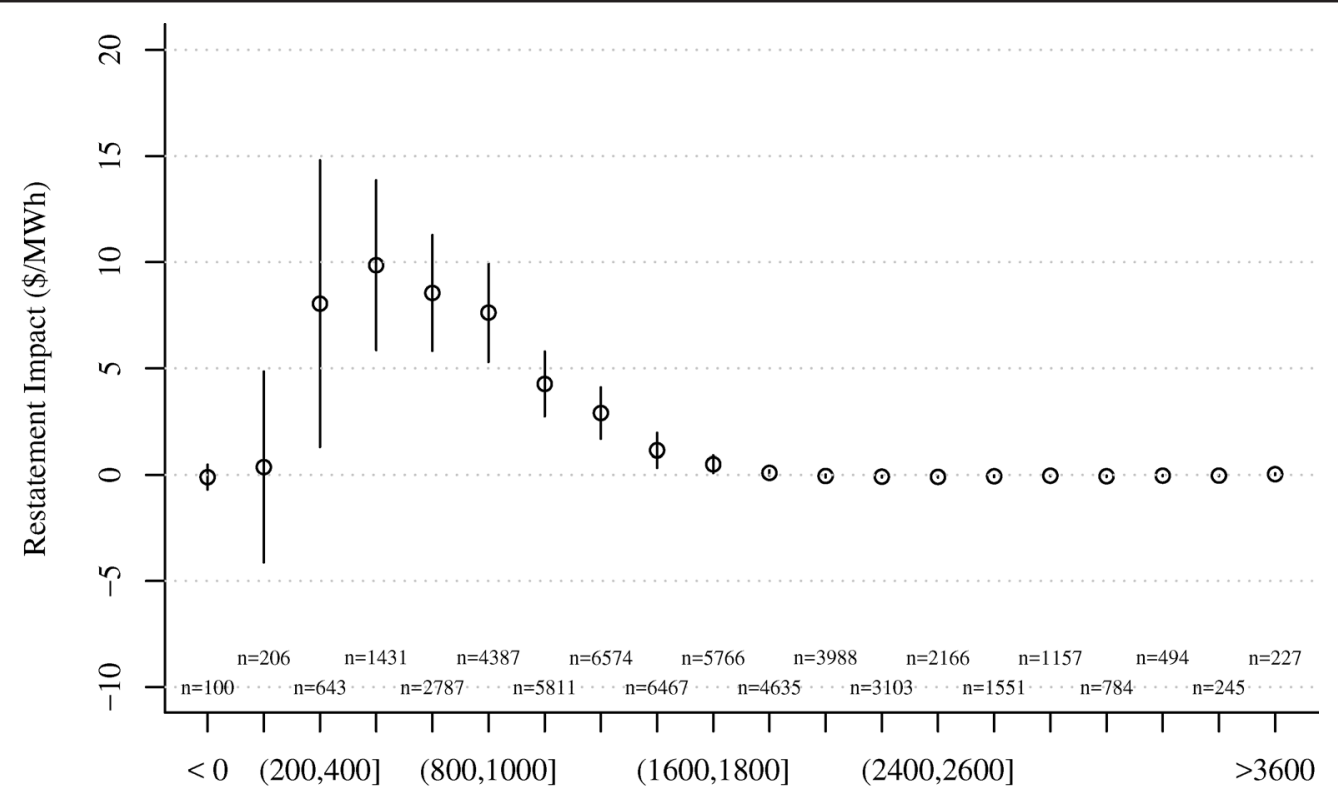

Supply cushion bin (MW)

\subsection{Hour-of-day effect}

Demand for electricity varies systematically across the hours of the day and is generally higher in the daytime than in the night-time. This pattern persists even though there is clear seasonality to electricity demand. Between these periods, demand will either increase or decrease. Since the ability to change a generator's level of production (so-called ramp rate) is not infinite, aggregate supply may also be constrained in these periods, especially when demand is increasing.

Following the argument in the previous section, it is expected that the average restatement impact will be higher in hours with (i) high or (ii) increasing demand. The reason is that it is during these periods that supply limitations (either the level or the ability to increase the level) are likely to give rise to market power.

The level of market price is likely to be correlated with the level of demand as well. This effect is likely to be strongest in the short-term when commitment decisions limit the amount of supply that is available. However, since economic agents are forward-looking, profit-seeking suppliers will commit more generation capacity when they expect demand to be higher. As a result, it is our experience that a measure like the supply cushion (the amount of available but unutilized supply) is far more likely to be related to the market price than the level of demand itself (to some extent, all of these variables are co-determined). It is for these reasons that hour-of-day (hour-ending or HE) fixed effects in considered, rather than the level of demand.

Measuring the relationship between restatement impacts and hour-ending is more straightforward than the analysis in the previous section because hour-ending is a discrete variable. Here, the restatement impact is regressed on a vector of hour-ending indicator variables. With the constant suppressed, the resulting coefficient and $95 \%$ confidence interval for each hour-ending is illustrated in Figure 6. 
Figure 6: 95\% confidence intervals for restatement impact by hour-ending

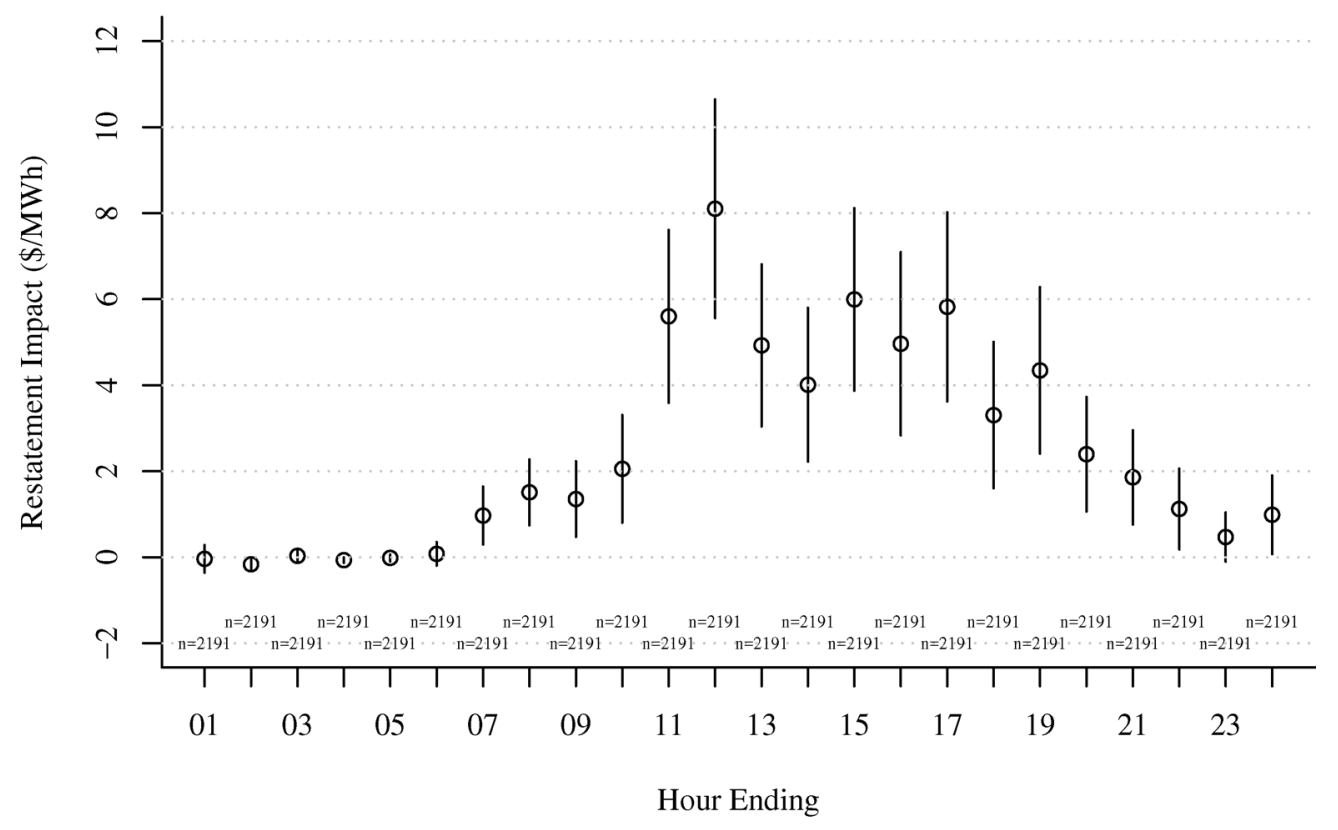

The restatement impact is statistically greater than zero in hour-ending 7 through 22 . These results are consistent with the expectations described above that the restatement impact is likely to be larger in hours with (i) high or (ii) increasing demand. In Alberta's electricity market, high demand hours are typically hours-ending 11 through 21 and increasing demand hours are typically hours-ending 7 through 10.

As expected, the restatement impact is not statistically different from zero in any of the other hour-endings with the exception of hour-ending 4 and 24, where the restatement impact is statistically negative. However, as Figure 6 illustrates, the estimate is less than $\$ 1 / \mathrm{MWh}$ and there is very little variation. This is consistent with there being little market power to act on in the middle of the night.

Taken together, these results are consistent with the expectations described above about the HTR facilitating learning that allows for the increased exercise of market power in hours with (i) high or (ii) increasing demand. These are the periods where supply limitations are likely to give rise to market power.

\subsection{Hour-of-day and yearly effects}

Recall that the results in Table 6 indicate that average restatement impacts vary across years. Since yearly variation may be due to macroeconomic factors that affect the market over lengthy periods of time, for example the commodity price downturn around 2014, year fixed effects can be used to account for these effects in a simple regression analysis. The equation takes the following form:

$$
\text { Impact }_{t}=\alpha+\sum_{y=2011}^{2015} \beta_{y} \text { Year }_{y t}+\sum_{h=2}^{24} \delta_{h} \text { HourEnding }_{h t}+\varepsilon_{t}
$$


where $t$ indexes the 52,584 hours in the data set and Year $_{y t}$ and HourEnding ${ }_{h t}$ are indicator variables for year and hour-ending, respectively.

The results of regressing the restatement impact on a set of hour-ending and yearly indicator variables is reported in Table 10. The year 2010 and the hour-ending 1 indicator variables are the ones that were omitted. The results indicate, for instance, that the average restatement impact in hour-ending 12 is $\$ 8.14 / \mathrm{MWh}$ and that this result is statistically significant at the $99 \%$ level of confidence. The estimate for later in the day, for example hour-ending 17 , is $\$ 5.86 / \mathrm{MWh}$ and is statistically significant at the same level of confidence. Regarding the yearly fixed effects, the year with the largest difference from 2010 is 2013 , when the average restatement impact was $\$ 3.33 / \mathrm{MWh}$ larger (in hour-ending 1) which is statistically significant at the $99 \%$ level of confidence.

These results confirm the findings above that, in the case of yearly effects, there is statistically significant variation across years. The variation and statistical significance of the hour-ending fixed effects is also consistent with the results above. Taken together, the results are consistent with the HTR facilitating learning that allows for the increased exercise of market power.

\section{CONCLUSION}

This paper considers the effect of the sharing of offer price information on the ability of non-cooperative producers to exercise unilateral market power in Alberta's hourly electricity market. This market is an hourly auction characterized by repeated interaction among a small number of producers, common knowledge of costs and production capabilities that are fixed in the short-run, and highly predictable and price inelastic demand. For the period July 13, 2000 to May 18, 2017, offer prices for a given hour were published by the market operator, called the Alberta Electric System Operator (AESO), in a report called the Historical Trading Report (HTR) about 5 to 10 minutes after the end of the hour.

Since non-cooperative game theory can support multiple equilibria in the context of a repeated game such as an hourly electricity auction, whether the publication of the HTR in the context of the specific facts of the Alberta electricity market increases or decreases competition is the empirical question, and is considered in this paper. Using counterfactual analysis on six years of data from 2010 to 2015 - 52,584 hours with total energy consumption of greater than $400 \mathrm{TWh}$ - that removes the changes to offers for the next hour for which restating offers is allowed following the most recent publication of the HTR, the paper finds that the effect of these offer price changes was to raise the average hourly price for electricity in Alberta by $\$ 2.48 / \mathrm{MWh}$ or about $4.2 \%$. This raised the aggregate value of electricity consumption in Alberta during the six-year period by approximately $\$ 1.14$ billion.

Further econometric analysis indicates that the impact of restatements increases as market conditions tighten, except when supply is nearly exhausted in which case prices are and would be very high with or without the HTR, and in periods where there is likely to be more market power, specifically the middle of the day and morning ramping up hours. These results are consistent with the HTR facilitating learning that allows for the increased exercise of market power.

It was on the basis of an earlier version of these results that the Market Surveillance Administrator, Alberta's electricity market monitor, filed an application with Alberta's electricity market regulator on December 2, 2015 seeking an order directing the AESO to cease publication of the HTR (or at least modify it substantially). ${ }^{19}$ On May 17, 2017, the Alberta Utilities Commission 
granted the Market Surveillance Administrator's application and ordered the AESO to cease publication of the HTR. ${ }^{20}$ Publication of the HTR ceased on May 18, 2017.

Information about current or recent producer offer strategies is not commonly available in other liberalised electricity markets. While this paper focuses on the release of certain offer information in the Alberta electricity market, the results suggest that other electricity markets should continue to be cautious about releasing offer information.

Finally, the database used in this study contained data over the time period 2010 to 2015. Given that publication of the HTR ceased in 2017 and the effect of the Balancing Pool began to lessen in mid-to-late 2018 (and is expected to disappear altogether at the end of 2020), it would be interesting to revisit this analysis once additional market data have accumulated after this time using a different methodology.

\section{ACKNOWLEDGMENTS}

The authors would like to thank the editor, Donald McFetridge, Adonis Yatchew, and five anonymous referees for their comments and feedback. All errors are our own.

\section{REFERENCES}

Alberta Electric System Operator (2012) "Price restatement period review" January 24.

Alberta Electric System Operator (2013) "ISO Rules. Part 200 Markets. Division 203 Energy Markets. Section 203.1, Energy Restatements." December 20.

Alberta Electric System Operator (2014) “ISO Rules. Part 200 Markets. Division 203 Energy Markets. Section 203.3, Energy Restatements." July 2.

Alberta Utilities Commission (2017) "Application by the Market Surveillance Administrator regarding the publication of the Historical Trading Report.” Alberta Utilities Commission Decision 21115-D01-2017. May 17.

Aroonruengsawat, Anin, Maximillian Auffhammer, and Alan H. Sanstad (2012). "The impacts of state level building codes on residential electricity consumption." The Energy Journal 33(1): 31-52. https://doi.org/10.5547/ISSN0195-6574-EJVol33-No1-2.

Bolle, Friedel (1992). "Supply function equilibria and the danger of tacit collusion." Energy Economics 14(2): 94-102. https://doi.org/10.1016/0140-9883(92)90002-U.

Brown, David P., Andrew Eckert, and James Lin (2018) "Information and transparency in wholesale electricity markets: Evidence from Alberta.” Journal of Regulatory Economics 54(3): 292-330, December. https://doi.org/10.1007/s11149018-9372-z.

Brown, David P. and Andrew Eckert (2019). "Pricing patterns in wholesale electricity markets: Unilateral market power or coordinated behavior?" University of Alberta Working Paper.

Brown, David P. and Derek E.H. Olmstead (2017). "Measuring market power and the efficiency of Alberta's restructured electricity market: An energy-only market design." Canadian Journal of Economics 50(3): 838-70, August. https://doi. org/10.1111/caje. 12280 .

Environment and Climate Change Canada: Historical Climate Data: Historical Data (undated). Available online at https://climate.weather.gc.ca/historical_data/search_historic_data_e.htmlhttps://climate.weather.gc.ca/historical_data/search_historic_data_e.html. Retrieved on June 2, 2019.

Fair, Efficient and Open Competition Regulation. Alberta Regulation 159/2009.

Fama, Eugene F., Lawrence Fisher, Michael C. Jensen, and Richard Roll (1969). "The adjustment of stock prices to new information.” International Economic Review 10: 1-21. https://doi.org/10.2307/2525569.

Green, Richard and David M. Newbery (1992). "Competition in the British electricity spot market." Journal of Political Economy, 100(5): 929-53. https://doi.org/10.1086/261846.

Holmberg, Par and David M. Newbery (2010). "The supply function equilibrium and its policy implications for wholesale electricity auctions.” Utilities Policy 18(4): 209-26. https://doi.org/10.1016/j.jup.2010.06.001.

20. Alberta Utilities Commission (2017).

All rights reserved. Copyright $(2020$ by the IAEE. 
Holmberg, Par and Frank A. Wolak (2018). "Comparing auction designs where suppliers have uncertain costs and uncertain pivotal status.” RAND Journal of Economics 49(4): 995-1027. https://doi.org/10.1111/1756-2171.12259.

Klemperer, Paul and Margaret Meyer (1989). "Supply function equilibria in oligopoly under uncertainty." Econometrica 57(6): 1243-77. https://doi.org/10.2307/1913707.

Kothari, S.P. and Jerold B. Warner (2007). “Econometrics of Event Studies.” In B. Espen Eckbo (ed.) Handbook of Empirical Corporate Finance (Volume A, Chapter 1), Elsevier/North-Holland.

Lijesen, Mark G. (2007). “The real-time price elasticity of electricity.” Energy Economics 29(2): 249-58. https://doi. org/10.1016/j.eneco.2006.08.008 .

Mansur, Erin (2008). "Measuring Welfare in Restructured Electricity Markets." The Review of Economics and Statistics 90(2): 369-386. https://doi.org/10.1162/rest.90.2.369.

Market Surveillance Administrator (2009). "2008 Year in Review.” May 14.

Market Surveillance Administrator (2012). "State of the market report 2012: An assessment of structure, conduct, and performance of Alberta's wholesale electricity market." December 10.

Market Surveillance Administrator (2013). "Coordinated effects and the Historical Trading Report: Decision and recommendation." August 7.

Market Surveillance Administrator (2015). "Application by the Market Surveillance Administrator in respect of the publication of Historical Trading Reports.” December 2.

Newey, Whitney K. and Kenneth D. West (1994). “Automatic lag selection in covariance matrix estimation.” Review of Economic Studies 61(4): 631-53. https://doi.org/10.2307/2297912.

Olmstead, Derek E. H. and Matthew J. Ayres (2014). "Notes from a small market: The energy-only market in Alberta." Electricity Journal, 27(4): 102-11. https://doi.org/10.1016/j.tej.2014.04.010.

Olmstead, Derek E. H. (2015). “Assessment of the impact of the Historical Trading Report on competition in the Alberta electricity market.” Exhibit number 21115-X0012, Alberta Utilities Commission Proceeding 21115, November 30.

Sweeting, Andrew (2007). "Market power In the England and Wales wholesale electricity market 1995-2000." Economic Journal 117(520): 654-85. https://doi.org/10.1111/j.1468-0297.2007.02045.x.

Vives, Xavier (2011). "Strategic supply function competition with private information." Econometrica 79: 1919-66. https:// doi.org/10.3982/ECTA8126.

Wolak, Frank A. (2003). "Measuring unilateral market power in wholesale electricity markets: The California market 19982000." American Economic Review Papers and Proceedings 92(2): 425-30. https://doi.org/10.1257/000282803321947461. 


\section{APPENDIX}

Table 8: Instrumental variables estimation of hourly price-responsive demand function

\begin{tabular}{|c|c|c|c|c|c|}
\hline \multirow[b]{2}{*}{ Depn. var:: } & \multirow[b]{2}{*}{$\begin{array}{c}O L S \\
\mathrm{Q}_{d}\end{array}$} & \multicolumn{2}{|c|}{ Lagged-price } & \multicolumn{2}{|c|}{ Supplyshifters } \\
\hline & & $\begin{array}{l}\text { First-stage } \\
\ln (1+\text { price })\end{array}$ & $\begin{array}{c}G M M \\
\mathrm{Q}_{d} \\
\end{array}$ & $\begin{array}{l}\text { First-stage } \\
\ln (1+\text { price })\end{array}$ & $\begin{array}{c}G M M \\
\mathrm{Q}_{d} \\
\end{array}$ \\
\hline $\ln (1+$ price $)$ & $\begin{array}{c}-33.670^{* * *} \\
(1.018)\end{array}$ & & $\begin{array}{c}-41.335^{* * * *} \\
(2.054)\end{array}$ & & $\begin{array}{c}-31.928 * * * \\
(1.775)\end{array}$ \\
\hline $\mathrm{HDH}_{e d m}$ & $\begin{array}{c}-0.996^{* *} \\
(0.397)\end{array}$ & $\begin{array}{c}0.002 \\
(0.005)\end{array}$ & $\begin{array}{c}-0.953 * * \\
(0.410)\end{array}$ & $\begin{array}{c}0.019 * * * \\
(0.004)\end{array}$ & $\begin{array}{c}-0.946^{* *} \\
(0.372)\end{array}$ \\
\hline $\mathrm{HDH}_{e d m}^{2}$ & $\begin{array}{l}0.016^{*} \\
(0.008)\end{array}$ & $\begin{array}{l}0.00005 \\
(0.0001)\end{array}$ & $\begin{array}{l}0.016^{*} \\
(0.009)\end{array}$ & $\begin{array}{l}-0.0001 \\
(0.0001)\end{array}$ & $\begin{array}{l}0.015^{*} \\
(0.008)\end{array}$ \\
\hline $\mathrm{HDH}_{c a l}$ & $\begin{array}{c}1.267 * * * \\
(0.371)\end{array}$ & $\begin{array}{c}-0.009 * \\
(0.005)\end{array}$ & $\begin{array}{c}1.125 * * * \\
(0.378)\end{array}$ & $\begin{array}{c}-0.026 * * * \\
(0.005)\end{array}$ & $\begin{array}{c}1.242 * * * \\
(0.357)\end{array}$ \\
\hline $\mathrm{HDH}_{c a l}^{2}$ & $\begin{array}{c}-0.023^{* *} \\
(0.009)\end{array}$ & $\begin{array}{c}0.0005^{* * * *} \\
(0.0001)\end{array}$ & $\begin{array}{c}-0.017 * \\
(0.009)\end{array}$ & $\begin{array}{c}0.001 * * * \\
(0.0001)\end{array}$ & $\begin{array}{c}-0.023 * * * \\
(0.009)\end{array}$ \\
\hline $\mathrm{CDH}_{e d m}$ & $\begin{array}{c}0.223 \\
(0.961)\end{array}$ & $\begin{array}{c}0.033 \\
(0.023)\end{array}$ & $\begin{array}{c}0.571 \\
(0.976)\end{array}$ & $\begin{array}{l}0.042 * \\
(0.023)\end{array}$ & $\begin{array}{l}-0.061 \\
(0.952)\end{array}$ \\
\hline $\mathrm{CDH}_{e d m}^{2}$ & $\begin{array}{c}-0.362 * * * \\
(0.110)\end{array}$ & $\begin{array}{l}0.006^{*} \\
(0.003)\end{array}$ & $\begin{array}{c}-0.297 * * * \\
(0.110)\end{array}$ & $\begin{array}{l}0.007 * * \\
(0.003)\end{array}$ & $\begin{array}{c}-0.365^{* * * *} \\
(0.111)\end{array}$ \\
\hline $\mathrm{CDH}_{c a l}$ & $\begin{array}{c}0.266 \\
(0.963)\end{array}$ & $\begin{array}{c}0.037 \\
(0.023)\end{array}$ & $\begin{array}{c}0.668 \\
(0.958)\end{array}$ & $\begin{array}{l}0.048 * * \\
(0.023)\end{array}$ & $\begin{array}{c}0.219 \\
(0.969)\end{array}$ \\
\hline $\mathrm{CDH}_{c a l}$ & $\begin{array}{l}-0.014 \\
(0.113)\end{array}$ & $\begin{array}{c}-0.0005 \\
(0.003)\end{array}$ & $\begin{array}{l}-0.017 \\
(0.113)\end{array}$ & $\begin{array}{c}-0.0003 \\
(0.003)\end{array}$ & $\begin{array}{l}-0.010 \\
(0.113)\end{array}$ \\
\hline Weekday & $\begin{array}{c}-17.284 * * * \\
(1.263)\end{array}$ & $\begin{array}{c}0.156^{* * * *} \\
(0.017)\end{array}$ & $\begin{array}{c}-15.850 * * * \\
(1.326)\end{array}$ & $\begin{array}{c}0.299 * * * \\
(0.017)\end{array}$ & $\begin{array}{c}-17.559^{* * * *} \\
(1.245)\end{array}$ \\
\hline Holiday & $\begin{array}{l}7.199 * * \\
(3.045)\end{array}$ & $\begin{array}{c}-0.193 * * * \\
(0.045)\end{array}$ & $\begin{array}{l}6.407 * * \\
(3.046)\end{array}$ & $\begin{array}{c}-0.316^{* * * *} \\
(0.041)\end{array}$ & $\begin{array}{l}7.353 * * \\
(3.032)\end{array}$ \\
\hline $\ln \left(\mathrm{p}^{N G}\right)$ & $\begin{array}{c}20.051 * * * \\
(5.285)\end{array}$ & $\begin{array}{c}0.306 * * * \\
(0.060)\end{array}$ & $\begin{array}{c}24.292 * * * \\
(5.474)\end{array}$ & $\begin{array}{c}0.558 * * * \\
(0.059)\end{array}$ & $\begin{array}{c}17.815^{* * * *} \\
(4.800)\end{array}$ \\
\hline $\ln \left(1+\mathrm{p}_{t-24}\right)$ & & $\begin{array}{c}0.376 * * * \\
(0.016)\end{array}$ & & & \\
\hline Capacity Avail. & & & & $\begin{array}{c}-0.001 * * * \\
(0.00003)\end{array}$ & \\
\hline Wind Prod, & & & & $\begin{array}{c}-0.0002 * * * \\
(0.00004)\end{array}$ & \\
\hline Constant & $\begin{array}{c}369.156^{* * * *} \\
(9.009)\end{array}$ & $\begin{array}{c}1.367 * * * \\
(0.109)\end{array}$ & $\begin{array}{c}386.499 * * * \\
(10.244)\end{array}$ & $\begin{array}{c}8.258 * * * \\
(0.259)\end{array}$ & $\begin{array}{c}366.629 * * * \\
(8.897)\end{array}$ \\
\hline Controls & Yes & Yes & Yes & Yes & Yes \\
\hline $\begin{array}{l}\text { Excl. Inst. F-stat: } \\
\text { Observations }\end{array}$ & 52,070 & $\begin{array}{c}566.74 * * * \\
52,046\end{array}$ & 52,046 & $\begin{array}{c}438.15^{* * * *} \\
52,070\end{array}$ & 52,070 \\
\hline$\overline{\mathrm{R}^{2}}$ & 0.455 & & & & \\
\hline
\end{tabular}

Note: Controls for year, month, and hour-ending. ${ }^{*} \mathrm{p}<0.1 ; * * \mathrm{p}<0.05 ; * * * \mathrm{p}<0.01$. 
Table 9: Instrumental variables estimation of hourly import supply functions

\begin{tabular}{|c|c|c|c|c|c|c|}
\hline \multirow[b]{2}{*}{ Depn. var:: } & \multicolumn{3}{|c|}{ Saskatchewan } & \multicolumn{3}{|c|}{ British Columbia/Montana } \\
\hline & $\begin{array}{l}O L S \\
\mathrm{Q}_{S K}^{I M} \\
\end{array}$ & $\begin{array}{l}\text { First-stage } \\
\ln (1+\text { price })\end{array}$ & $\begin{array}{c}G M M \\
\mathrm{Q}_{S K}^{I M} \\
\end{array}$ & $\begin{array}{l}O L S \\
\mathrm{Q}_{B C}^{I M} \\
\end{array}$ & $\begin{array}{l}\text { First-stage } \\
\ln (1+\text { price })\end{array}$ & $\begin{array}{c}G M M \\
\mathrm{Q}_{B C}^{I M}\end{array}$ \\
\hline $\ln (1+$ price $)$ & $\begin{array}{c}11.260^{* * * *} \\
(0.921)\end{array}$ & & $\begin{array}{c}21.442 * * * \\
(3.469)\end{array}$ & $\begin{array}{c}23.489 * * * \\
(3.630)\end{array}$ & & $\begin{array}{c}177.120 * * * \\
(14.536)\end{array}$ \\
\hline $\mathrm{HDH}_{j}$ & $\begin{array}{c}0.855 * * * \\
(0.279)\end{array}$ & $\begin{array}{c}0.014^{* *} \\
(0.005)\end{array}$ & $\begin{array}{c}0.799 * * * \\
(0.285)\end{array}$ & $\begin{array}{c}14.863 * * * \\
(2.214)\end{array}$ & $\begin{array}{c}-0.049 * * * \\
(0.011)\end{array}$ & $\begin{array}{c}21.793 * * * \\
(2.855)\end{array}$ \\
\hline $\mathrm{HDH}_{j}^{2}$ & $\begin{array}{c}-0.012 * * * \\
(0.005)\end{array}$ & $\begin{array}{c}-0.0003 * * * \\
(0.0001)\end{array}$ & $\begin{array}{c}-0.015 * * * \\
(0.005)\end{array}$ & $\begin{array}{c}-0.442 * * * \\
(0.091)\end{array}$ & $\begin{array}{c}0.001 * * * \\
(0.0004)\end{array}$ & $\begin{array}{c}-0.828 * * * \\
(0.114)\end{array}$ \\
\hline $\mathrm{CDH}_{j}$ & $\begin{array}{l}-1.024 \\
(0.948)\end{array}$ & $\begin{array}{l}-0.010 \\
(0.019)\end{array}$ & $\begin{array}{c}-1.799^{*} \\
(1.013)\end{array}$ & $\begin{array}{c}18.826^{* * * *} \\
(5.802)\end{array}$ & $\begin{array}{l}0.0003 \\
(0.029)\end{array}$ & $\begin{array}{c}3.011 \\
(7.367)\end{array}$ \\
\hline $\mathrm{CDH}_{j}^{2}$ & $\begin{array}{c}0.035 \\
(0.100)\end{array}$ & $\begin{array}{c}0.005^{* *} \\
(0.003)\end{array}$ & $\begin{array}{l}-0.011 \\
(0.115)\end{array}$ & $\begin{array}{l}-0.246 \\
(0.884)\end{array}$ & $\begin{array}{l}-0.002 \\
(0.005)\end{array}$ & $\begin{array}{l}-0.012 \\
(1.091)\end{array}$ \\
\hline Weekday & $\begin{array}{c}1.068 \\
(1.717)\end{array}$ & $\begin{array}{c}0.191 * * * \\
(0.021)\end{array}$ & $\begin{array}{l}-0.776 \\
(1.912)\end{array}$ & $\begin{array}{c}34.132 * * * \\
(6.422)\end{array}$ & $\begin{array}{c}0.195 * * * \\
(0.021)\end{array}$ & $\begin{array}{c}5.900 \\
(7.268)\end{array}$ \\
\hline Holiday & $\begin{array}{l}-2.561 \\
(4.456)\end{array}$ & $\begin{array}{c}-0.282 * * * \\
(0.051)\end{array}$ & $\begin{array}{c}0.989 \\
(4.326)\end{array}$ & $\begin{array}{c}-38.151^{* *} \\
(17.988)\end{array}$ & $\begin{array}{c}-0.282 * * * \\
(0.051)\end{array}$ & $\begin{array}{c}14.609 \\
(19.550)\end{array}$ \\
\hline $\mathrm{HDH}_{e d m}$ & & $\begin{array}{c}0.003 \\
(0.006)\end{array}$ & & & $\begin{array}{c}0.016^{* *} \\
(0.006)\end{array}$ & \\
\hline $\mathrm{HDH}_{c a l}$ & & $\begin{array}{c}-0.023 * * * \\
(0.006)\end{array}$ & & & $\begin{array}{c}-0.014 * * \\
(0.006)\end{array}$ & \\
\hline $\mathrm{HDH}_{e d m}^{2}$ & & $\begin{array}{c}0.0002 \\
(0.0001)\end{array}$ & & & $\begin{array}{l}-0.0001 \\
(0.0001)\end{array}$ & \\
\hline $\mathrm{HDH}_{c a l}^{2}$ & & $\begin{array}{l}0.001 * * * \\
(0.0002)\end{array}$ & & & $\begin{array}{c}0.001 * * * \\
(0.0002)\end{array}$ & \\
\hline $\mathrm{CDH}_{e d m}$ & & $\begin{array}{l}0.047^{*} \\
(0.026)\end{array}$ & & & $\begin{array}{l}0.048^{*} \\
(0.027)\end{array}$ & \\
\hline $\mathrm{CDH}_{c a l}$ & & $\begin{array}{c}0.045 \\
(0.028)\end{array}$ & & & $\begin{array}{l}0.048^{*} \\
(0.027)\end{array}$ & \\
\hline $\mathrm{CDH}_{e d m}^{2}$ & & $\begin{array}{l}0.007 * \\
(0.004)\end{array}$ & & & $\begin{array}{c}0.009 * * \\
(0.004)\end{array}$ & \\
\hline $\mathrm{CDH}_{c a l}$ & & $\begin{array}{l}-0.002 \\
(0.004)\end{array}$ & & & $\begin{array}{l}0.0001 \\
(0.004)\end{array}$ & \\
\hline Constant & $\begin{array}{c}-30.732 * * * \\
(6.387)\end{array}$ & $\begin{array}{c}2.849 * * * \\
(0.106)\end{array}$ & $\begin{array}{c}-58.592 * * * \\
(11.549)\end{array}$ & $\begin{array}{c}-124.544^{* * *} \\
(24.672)\end{array}$ & $\begin{array}{c}3.155 * * * \\
(0.112)\end{array}$ & $\begin{array}{c}-649.128 * * * \\
(56.314)\end{array}$ \\
\hline Controls & Yes & Yes & Yes & Yes & Yes & Yes \\
\hline Excl. Inst. F-stat: & & $27.42 * * *$ & & & $40.83 * * *$ & \\
\hline Observations & 52,070 & 52,070 & 52,070 & 52,070 & 52,070 & 52,070 \\
\hline $\mathrm{R}^{2}$ & 0.295 & & & 0.415 & & \\
\hline
\end{tabular}

Note: Controls for year, month, and hour-ending. $* \mathrm{p}<0.1 ; * * \mathrm{p}<0.05 ; * * * \mathrm{p}<0.01$. 
Table 10: Regression analysis of time fixed effects on restatement impact

\begin{tabular}{|c|c|}
\hline & Dependent variable: \\
\hline & Impact (\$/MWh) \\
\hline Year 2011 & $1.604 * *(0.660)$ \\
\hline Year 2012 & $0.999 * *(0.481)$ \\
\hline Year 2013 & $3.332 * * *(0.770)$ \\
\hline Year 2014 & $2.193 * *(1.029)$ \\
\hline Year 2015 & $2.014 * *(0.896)$ \\
\hline HE 02 & $-0.126(0.138)$ \\
\hline HE 03 & $0.070(0.172)$ \\
\hline HE 04 & $-0.030(0.166)$ \\
\hline HE 05 & $0.023(0.176)$ \\
\hline HE 06 & $0.115(0.212)$ \\
\hline HE 07 & $1.005 * * *(0.374)$ \\
\hline HE 08 & $1.547 * * *(0.411)$ \\
\hline HE 09 & $1.390 * * *(0.471)$ \\
\hline HE 10 & $2.093 * * *(0.660)$ \\
\hline HE 11 & $5.638 * * *(1.026)$ \\
\hline HE 12 & $8.140 * * *(1.292)$ \\
\hline HE 13 & $4.964 * * *(0.968)$ \\
\hline HE 14 & $4.048 * * *(0.918)$ \\
\hline HE 15 & $6.032 * * *(1.092)$ \\
\hline HE 16 & $5.000 * * *(1.092)$ \\
\hline HE 17 & $5.858 * * *(1.115)$ \\
\hline HE 18 & $3.341 * * *(0.877)$ \\
\hline HE 19 & $4.382 * * *(0.987)$ \\
\hline HE 20 & $2.432 * * *(0.675)$ \\
\hline HE 21 & $1.895 * * *(0.566)$ \\
\hline HE 22 & $1.159 * *(0.478)$ \\
\hline HE 23 & $0.507(0.308)$ \\
\hline HE 24 & $1.025 * *(0.439)$ \\
\hline Constant & $-1.726 * * *(0.417)$ \\
\hline Observations & 52,584 \\
\hline $\mathrm{R}^{2}$ & 0.007 \\
\hline F Statistic & $4.9023 * * *$ \\
\hline
\end{tabular}

